\title{
Soil Microbial Indicators within Rotations and Tillage Systems
}

\author{
Gevan D. Behnke ${ }^{1} \mathbb{D}$, Nakian Kim ${ }^{1}$, Maria C. Zabaloy ${ }^{2} \mathbb{D}$, Chance W. Riggins $^{1}$, Sandra Rodriguez-Zas ${ }^{3}$ \\ and Maria B. Villamil ${ }^{1, *(D)}$ \\ 1 Department of Crop Sciences, University of Illinois, Urbana, IL 61801, USA; \\ gbehnke2@illinois.edu (G.D.B.); nakhyun2@illinois.edu (N.K.); cwriggin@illinois.edu (C.W.R.) \\ 2 Centro de Recursos Naturales Renovables de la Zona Semiárida (CERZOS, UNS-CONICET), \\ Departamento de Agronomía, Universidad Nacional del Sur, Bahia Blanca B8000, Argentina; \\ mzabaloy@uns.edu.ar \\ 3 Department of Animal Sciences, University of Illinois, Urbana, IL 61801, USA; rodrgzzs@illinois.edu \\ * Correspondence: villamil@illinois.edu
}

Citation: Behnke, G.D.; Kim, N.; Zabaloy, M.C.; Riggins, C.W.;

Rodriguez-Zas, S.; Villamil, M.B. Soil Microbial Indicators within Rotations and Tillage Systems. Microorganisms 2021, 9, 1244. https://doi.org/ 10.3390/microorganisms 9061244

Academic Editor: Tim J. Dumonceaux

Received: 19 May 2021

Accepted: 6 June 2021

Published: 8 June 2021

Publisher's Note: MDPI stays neutral with regard to jurisdictional claims in published maps and institutional affiliations.

Copyright: (c) 2021 by the authors. Licensee MDPI, Basel, Switzerland. This article is an open access article distributed under the terms and conditions of the Creative Commons Attribution (CC BY) license (https:/ / creativecommons.org/licenses/by/ $4.0 /)$.

\begin{abstract}
Recent advancements in agricultural metagenomics allow for characterizing microbial indicators of soil health brought on by changes in management decisions, which ultimately affect the soil environment. Field-scale studies investigating the microbial taxa from agricultural experiments are sparse, with none investigating the long-term effect of crop rotation and tillage on microbial indicator species. Therefore, our goal was to determine the effect of rotations (continuous corn, CCC; continuous soybean, SSS; and each phase of a corn-soybean rotation, Cs and Sc) and tillage (no-till, NT; and chisel tillage, T) on the soil microbial community composition following 20 years of management. We found that crop rotation and tillage influence the soil environment by altering key soil properties, such as $\mathrm{pH}$ and soil organic matter (SOM). Monoculture corn lowered $\mathrm{pH}$ compared to SSS (5.9 vs. 6.9 , respectively) but increased SOM (5.4\% vs. $4.6 \%$, respectively). Bacterial indicator microbes were categorized into two groups: SOM dependent and acidophile vs. $\mathrm{N}$ adverse and neutrophile. Fungi preferred the CCC rotation, characterized by low $\mathrm{pH}$. Archaeal indicators were mainly ammonia oxidizers with species occupying niches at contrasting $\mathrm{pHs}$. Numerous indicator microbes are involved with $\mathrm{N}$ cycling due to the fertilizer-rich environment, prone to aquatic or gaseous losses.
\end{abstract}

Keywords: bacteria; fungi; archaea; metagenomics; microbial N cycle; nitrification; maize; soybean; monocultures; no tillage

\section{Introduction}

Agricultural management practices influence soil microbial communities, creating niche environments that favor certain microbes [1,2]. Management practices can include crop rotation, tillage, $\mathrm{N}$ fertilization, cover cropping, etc. By selecting management practices or combining them, the soil environment is altered, as are essential soil processes. These can include residue decomposition, nutrient and water cycling, aeration and gaseous interactions, development of soil aggregates, soil organic matter (SOM) dynamics, and biodiversity measures [3,4]. Crop rotation is a common management practice with benefits that include pest and disease control and yield improvement and stabilization [5-7]. Tillage is another tool used to improve yields by creating a more favorable environment for cash crop growth. In systems of high organic matter, tillage ensures a clean seedbed for early growth by reducing compaction, improving aeration, increasing soil temperature, and removing weed competition $[5,8,9]$. Lastly, $\mathrm{N}$ fertilization is a common practice used to enhance yields, and that influx of previously scarce $\mathrm{N}$ reshapes potential $\mathrm{N}$ dynamics controlled by soil microbial communities [10].

Given the benefits of crop rotation, tillage, and $\mathrm{N}$ fertilization on crop yields, their implementation is widespread, which affects the soil microbial community. Crop rotation 
and fertilization alter the quantity and quality of crop residues, root exudates, and subsequent rhizodeposits [11-13]. Results from a meta-analysis by Ouyang et al. [14] showed that crop rotation and soil $\mathrm{pH}$ influenced $\mathrm{N}$ cycling by changing the ammonia-oxidizing bacteria (AOB) and archaea (AOA) community dynamics, as well as denitrifiers. Crop rotation increased AOB levels compared to monocultures; AOA was unaffected. However, neutrophilic soil conditions led to an increase in both AOA and AOB. Furthermore, N fertilization increased the abundance of $\mathrm{AOA}, \mathrm{AOB}$, and denitrifiers [14]. In a remarkably long-term study on the Morrow Plots in Urbana, IL, treatments of crop rotation and $\mathrm{N}$ fertilization have been in place since 1876; shifts in microbial functions related to substrate utilization were affected by fertilizer treatments more than crop rotation given the chronic nutrient limitations and changes in soil chemistry [15]. Smith et al. [16] reported that crop type and tillage altered species composition, but not quantity and diversity metrics from Indiana corn (Zea mays L.)-soybean [Glycine max (L.) Merr.] rotations. Compared to crop rotation, tillage had a larger effect on nutrient levels, which was a better predictor for microbial community composition [16]. The effects of tillage on the soil microbial community include mechanically disrupting growth and distribution, destroying soil aggregates, reducing soil moisture, increasing soil temperature, and degrading soil organic matter (SOM) [17-19]. In a global meta-analysis looking at the effects of tillage, Zuber and Villamil [20] observed that NT systems have greater microbial biomass and enzymatic activities. Furthermore, de Graaff et al. [21], also using a meta-analytic approach, showed that tillage decreased bacterial biodiversity, however, it did not affect fungi.

Previously when technology was a limiting factor, using broad inference measurements was the best available technique for explaining how the soil microbiome responds to management factors. However, new metagenomic approaches better characterize the microbial community composition and function and its relationship with soil properties and agronomics [22-24]. Diversity and richness metrics represent the variability within a single sample ( $\alpha$-diversity) and among communities ( $\beta$-diversity). Using quantitative polymerase chain reaction (qPCR), functional microbial genes, such as nirK, which is involved in denitrification, are analyzed for treatment effects [10,25]. Lastly, using primers for each major taxonomic group (bacteria, fungi, and archaea, PCR amplification produces a vast pool of amplicons. From that pool of hundreds to thousands of individual amplicons, high throughput sequencing with Illumina yields a deep inventory of amplicon sequence variants (ASVs), from where indicator microbes can be selected and characterized [22,23]. Indicator microbes usually refer to an ASV that explains variability in a dataset [23]. Studies on indicator microbes have shown that organic matter inputs and $\mathrm{pH}$ alter the cycling of $\mathrm{N}$ and $\mathrm{C}$, resulting in significant changes in soil biological properties $[2,15,26,27]$. Given the complexity of using metagenomics to identify indicator microbes, field studies are scarce, especially from a long-term setting. A few long-term studies (15-130 years) have determined indicator microbes from typical cropping systems $[2,15,27]$, though none have analyzed crop rotation and tillage simultaneously. As these are the most common tools used by growers to improve yields, a thorough investigation of these indicator microbes is necessary.

We hypothesized that our treatments of continuous corn and soybean would show contrasting effects on microbial taxa, with rotated corn-soybean having intermediate results, not different from either monoculture. We also hypothesized that $\mathrm{AOB}$ and fungi would have elevated abundances in the continuous corn treatment, with AOA increasing in the continuous soybean treatment. Therefore, the objective of this investigation was to identify microbial taxa that were responsive to crop rotation and tillage from a long-term, stable trial (20+ years). The results will add valuable primary information on how the soil microorganisms shift in response to common agricultural management practices. 


\section{Materials and Methods}

\subsection{Experimental Site Description and Management Practices}

The experiment was conducted at the Northwestern Illinois Agricultural Research and Demonstration Center $\left(40^{\circ} 55^{\prime} 50^{\prime \prime} \mathrm{N}, 90^{\circ} 43^{\prime} 38^{\prime \prime} \mathrm{W}\right)$, near Monmouth, Illinois. The study was established in 1996, and a complete description of the site can be found in Behnke et al. (2018; 2020). Briefly, soils were comprised of highly fertile silty clay loam and silt loam soil series (Muscatune 43\%, Sable 40\%, and Osco 17\%) [28]. The study was designed in a split-plot arrangement of 4 rotation levels and 2 tillage levels in a randomized complete block design with 4 replications (blocks). The main plots $(22 \mathrm{~m}$ long by $12 \mathrm{~m}$ wide) were crop rotation treatments, which consisted of continuous corn (CCC), corn phase of the corn-soybean rotation (Cs), soybean phase of the corn-soybean rotation (Sc), and continuous soybean (SSS). Subplot (22 $\mathrm{m}$ long by $6 \mathrm{~m}$ wide) tillage options were either no-till (NT) or chisel tillage (T). Tillage occurred in the fall following harvest using a diskripper to $35 \mathrm{~cm}$ in depth, and in the spring, a soil finisher was used to prepare the seedbeds. No-till plots received zero tillage. Spring $\mathrm{N}$ fertilizer was applied at or before planting as injected incorporated urea ammonium nitrate (UAN) at a rate of $246 \mathrm{~kg} \mathrm{~N} \mathrm{ha}^{-1}$ for CCC and $202 \mathrm{~kg} \mathrm{~N} \mathrm{ha}^{-1}$ for Cs; soybeans received no fertilizer. Fertilizer and pest management followed the Illinois Agronomy Handbook [29]. Key field event date ranges are provided in Table S1.

\subsection{Soil Sampling and Procedures}

Soil samples were taken postharvest in October of 2015 and 2016 using an Eijkelkamp grass plot sampler (Eijkelkamp Soil and Water, Morrisville, NC, USA) to a depth of $10 \mathrm{~cm}$. A total of 3 subsamples were taken for each plot; each subsample consisted of around 10 random plugs totaling $\sim 500 \mathrm{~g}$ of soil per subsample. A complete, multivariate examination of soil properties was conducted in Behnke, Zabaloy, Riggins, Rodriguez-Zas, Huang and Villamil [25], and a table summarizing that information was provided in the supplementary information Table S2. Soil samples were immediately preserved with ice then frozen to $-20{ }^{\circ} \mathrm{C}$ after returning to the lab facilities. Using $0.25 \mathrm{~g}$ of soil per composited subsample, soil DNA was extracted using the PowerSoil ${ }^{\circledR}$ DNA isolation kits (MoBio Inc., Carlsbad, CA, USA), following the included instructions. The extracted DNA was then measured for quantity and quality using a Nanodrop 100 Spectrophotometer (Thermo Fisher Scientific, Waltham, MA, USA) and stored at $-20^{\circ} \mathrm{C}$. Amplification of the Bacterial 16S rRNA gene (V4 region) used a primer set of 515F (GTGYCAGCMGCCGCGGTAA) and 806R (GGACTACVSGGGTWTCTAAT) [26], archaeal 16S used 349F (GTGCASCAGKCGMGAAW) and 806R (GGACTACVSGGGTATCTAAT) [30], and fungal ITS (internal transcribed spacer) region used 3F (GCATCGATGAAGAACGCAGC) and 4R (TCCTCCGCTTATTGATATGC) [31]. The primers were designed as a 50-PCRspecific + gene region +30 -PCR-specific $+10 \mathrm{nt}$ barcode, and the Fluidigm platform used 2 primer sets concurrently in the creation of the final DNA amplicon. A Qubit Fluorometer (Thermo Fisher Scientific, Waltham, MA, USA) quantified the resulting amplicon libraries, which were then computed using a Bioanalyzer (Agilent, Santa Clara, CA, USA) to evaluate the profile of fragment lengths. The barcoded libraries were combined in equimolar concentrations and diluted to $10 \mathrm{nM}$. The diluted libraries were sequenced at the Roy Carver Biotechnology Center Functional Genomics lab at the University of Illinois at Urbana-Champaign (Urbana, IL, USA) using paired-end sequencing on the Illumina HiSeq (Illumina, San Diego, CA, USA), resulting in $250 \mathrm{nt}$ long reads.

\subsection{Bioinformatics Analysis}

Using QIIME2 [32,33], the sequences were processed and checked for quality. Next, the demultiplexed sequences were filtered using a $Q$ score threshold of 30 [34], which resulted in the retention of bacterial sequences between base-pair positions 6 to 231, fungal sequences 6 to 222, and archaeal sequences 6 to 221. Then, chimeric and low-quality sequences were removed by the denoising option (chimera-method consensus) in the plugin 
DADA2 [35]. The product of those steps was ASVs, which were then aligned with MAFFT (v7) [36] to generate the phylogenetic tree using FastTree [37] for $\beta$-diversity measurements. In Qiime 2.0, the option feature-classifier classify-sklearn was used to classify the ASVs with reference sequences in the SILVA ribosomal RNA gene database (silva-13299-515-806-nb-classifier_2019_4) (Quast et al., 2013) and Fungi_97_classifier_2019_4. The rarefaction curves plateaued at sampling depths of 35,100 bacterial sequences per sample, 10,000 fungal sequences per sample, and 1000 archaeal sequences per sample (Figure S1). Using these depths, QIIME2 produced the number of observed ASVs, Pielou's Evenness Index, and Shannon's Diversity Index $\left(\mathrm{H}^{\prime}\right)$ for each sample (shown in Table 1). Similarly, QIIME2 calculated $\beta$-diversity measurements for each taxa using weighted UniFrac distances (Tables 3-4). The rarefaction curves (Figure S1) were produced using SigmaPlot (v. 12.5 Systat Software, Inc., San Jose, CA, USA).

Table 1. Mean values and standard errors of the mean (SEM) for the $\alpha$-diversity parameters of observed amplicon sequence variants (ASVs), Pielou Evenness Index (Pielou), and Shannon's Diversity Index ( $\left.\mathrm{H}^{\prime}\right)$ for bacteria, fungi, and archaea taxa, following 20 years of crop rotation and tillage treatments. For each taxon group and within a given column, treatment mean values followed by the same lowercase letter were not statistically different $(\alpha=0.05)$.

\begin{tabular}{|c|c|c|c|c|c|c|c|c|c|c|}
\hline \multirow[b]{2}{*}{ Taxa } & \multirow[b]{2}{*}{ Treatment } & \multicolumn{3}{|c|}{ ASVs } & \multicolumn{3}{|c|}{ Pielou } & \multicolumn{3}{|c|}{$\mathbf{H}^{\prime}$} \\
\hline & & Mean & SEM & $p$-Value & Mean & SEM & $p$-Value & Mean & SEM & $p$-Value \\
\hline \multirow{6}{*}{ Bacteria } & $\mathrm{CCC}^{+}$ & 1297.08 & \multirow{4}{*}{62.29} & \multirow{4}{*}{0.42} & 0.97 & \multirow{4}{*}{0.00} & \multirow{4}{*}{0.99} & 10.00 & \multirow{4}{*}{0.07} & \multirow{4}{*}{0.30} \\
\hline & Cs & 1377.79 & & & 0.97 & & & 10.12 & & \\
\hline & $\mathrm{Sc}$ & 1384.50 & & & 0.97 & & & 10.14 & & \\
\hline & SSS & 1445.19 & & & 0.97 & & & 10.20 & & \\
\hline & $\mathrm{NT} \ddagger$ & 1380.71 & \multirow{2}{*}{44.05} & \multirow{2}{*}{0.88} & 0.97 & \multirow{2}{*}{0.00} & \multirow{2}{*}{0.53} & 10.12 & \multirow[b]{2}{*}{0.05} & \multirow[b]{2}{*}{0.83} \\
\hline & $\mathrm{T}$ & 1371.57 & & & 0.97 & & & 10.11 & & \\
\hline \multirow{6}{*}{ Fungi } & $\mathrm{CCC}$ & $30.56 \mathrm{a}$ & \multirow{4}{*}{2.09} & \multirow{4}{*}{0.01} & 0.82 & \multirow{4}{*}{0.01} & \multirow{4}{*}{0.33} & $3.97 \mathrm{a}$ & \multirow{4}{*}{0.12} & \multirow{4}{*}{0.03} \\
\hline & Cs & $29.50 \mathrm{ab}$ & & & 0.80 & & & $3.85 \mathrm{ab}$ & & \\
\hline & Sc & $25.17 \mathrm{ab}$ & & & 0.80 & & & $3.63 \mathrm{ab}$ & & \\
\hline & SSS & $23.90 \mathrm{~b}$ & & & 0.79 & & & $3.54 \mathrm{~b}$ & & \\
\hline & NT & 27.81 & \multirow{2}{*}{1.73} & \multirow{2}{*}{0.52} & 0.79 & \multirow{2}{*}{0.01} & \multirow{2}{*}{0.18} & 3.73 & \multirow{2}{*}{0.09} & \multirow{2}{*}{0.78} \\
\hline & $\mathrm{T}$ & 26.75 & & & 0.81 & & & 3.77 & & \\
\hline \multirow{6}{*}{ Archaea } & $\mathrm{CCC}$ & 64.34 & \multirow{4}{*}{6.22} & \multirow{4}{*}{0.80} & 0.93 & & & 5.54 & & \\
\hline & Cs & 65.64 & & & 0.94 & & & 5.55 & & \\
\hline & Sc & 69.79 & & & 0.94 & 0.00 & 0.51 & 5.65 & 0.14 & 0.83 \\
\hline & SSS & 70.87 & & & 0.94 & & & 5.68 & & \\
\hline & NT & 68.81 & & & 0.94 & & & 5.63 & & \\
\hline & $\mathrm{T}$ & 66.51 & 4.86 & 0.68 & 0.94 & 0.00 & 0.85 & 5.58 & 5.63 & 0.69 \\
\hline
\end{tabular}

${ }^{\dagger} \mathrm{CCC}$, continuous corn; Cs, corn phase of the corn-soybean rotation; Sc, soybean phase of the corn-soybean rotation; SSS, continuous soybean. ${ }^{\mathrm{N} T}$, no-till; T, chisel tillage.

Table 2. Community structure ( $\beta$-diversity) measures for bacteria following 20 years of crop rotation and tillage treatments, and their interaction, based on pairwise permanova computation of weighted unifrac distances. The pseudo-F column represents the comparison between UniFrac distances for a given treatment combination (listed in the Treatments Compared column). The $p$-value and q-value columns indicate the probability of type I and type II errors associated with the treatment comparisons, respectively.

\begin{tabular}{cccccc}
\hline Treatment & Treatments Compared & Sample Size & Pseudo-F & $p$-Value & q-Value \\
\hline & CCC-Cs & 96 & 3.97 & 0.0010 & 0.0012 \\
\multirow{3}{*}{ Rotation $^{+}$} & CCC-SSS & 96 & 15.14 & 0.0010 & 0.0012 \\
& CCC-Sc & 96 & 5.35 & 0.0010 & 0.0012 \\
& Cs-SSS & 96 & 6.10 & 0.0010 & 0.0012 \\
& Cs-Sc & 96 & 1.30 & 0.1600 & 0.1600 \\
\hline
\end{tabular}


Table 2. Cont.

\begin{tabular}{|c|c|c|c|c|c|}
\hline Treatment & Treatments Compared & Sample Size & Pseudo-F & $p$-Value & q-Value \\
\hline \multirow[t]{14}{*}{ Tillage $\ddagger$} & NT-T & 192 & 5.45 & 0.0010 & 0.0010 \\
\hline & CCCNT-CCCT & 48 & 3.11 & 0.0030 & 0.0047 \\
\hline & CCCNT-CsNT & 48 & 2.85 & 0.0040 & 0.0053 \\
\hline & CCCNT-CsT & 48 & 5.54 & 0.0010 & 0.0020 \\
\hline & CCCNT-SSSNT & 48 & 8.31 & 0.0010 & 0.0020 \\
\hline & CCCNT-SSST & 48 & 11.37 & 0.0010 & 0.0020 \\
\hline & CCCNT-ScNT & 48 & 3.12 & 0.0050 & 0.0064 \\
\hline & CCCNT-ScT & 48 & 7.01 & 0.0010 & 0.0020 \\
\hline & CCCT-CsNT & 48 & 1.94 & 0.0200 & 0.0224 \\
\hline & CCCT-CsT & 48 & 2.71 & 0.0020 & 0.0035 \\
\hline & CCCT-SSSNT & 48 & 7.57 & 0.0010 & 0.0020 \\
\hline & CCCT-SSST & 48 & 9.49 & 0.0010 & 0.0020 \\
\hline & CCCT-ScNT & 48 & 2.93 & 0.0010 & 0.0020 \\
\hline & CCCT-ScT & 48 & 3.64 & 0.0010 & 0.0020 \\
\hline \multirow{15}{*}{ Rotation $\times$ Tillage ${ }^{\bullet}$} & CsNT-CsT & 48 & 1.76 & 0.0310 & 0.0334 \\
\hline & CsNT-SSSNT & 48 & 3.49 & 0.0020 & 0.0035 \\
\hline & CsNT-SSST & 48 & 5.89 & 0.0010 & 0.0020 \\
\hline & CsNT-ScNT & 48 & 0.85 & 0.6340 & 0.6340 \\
\hline & CsNT-ScT & 48 & 2.02 & 0.0110 & 0.0128 \\
\hline & CsT-SSSNT & 48 & 3.37 & 0.0010 & 0.0020 \\
\hline & CsT-SSST & 48 & 3.57 & 0.0010 & 0.0020 \\
\hline & CsT-ScNT & 48 & 2.68 & 0.0040 & 0.0053 \\
\hline & CsT-ScT & 48 & 1.30 & 0.1400 & 0.1452 \\
\hline & SSSNT-SSST & 48 & 2.07 & 0.0080 & 0.0097 \\
\hline & SSSNT-ScNT & 48 & 3.04 & 0.0030 & 0.0047 \\
\hline & SSSNT-ScT & 48 & 2.67 & 0.0010 & 0.0020 \\
\hline & SSST-ScNT & 48 & 6.17 & 0.0010 & 0.0020 \\
\hline & SSST-ScT & 48 & 3.20 & 0.0010 & 0.0020 \\
\hline & ScNT-ScT & 48 & 2.43 & 0.0040 & 0.0053 \\
\hline
\end{tabular}

${ }^{\dagger}$ CCC, continuous corn; Cs, corn phase of the corn-soybean rotation; Sc, soybean phase of the corn-soybean rotation; SSS, continuous soybean. ${ }^{\ddagger}$ NT, no-till; T, chisel tillage. $•$ CCCNT, continuous corn, and no-till; CCCT, continuous corn, and chisel tillage; CsNT, corn phase of the corn-soybean rotation and no-till; CsT, corn phase of the corn-soybean rotation and chisel tillage; ScNT, soybean phase of the corn-soybean rotation and no-till; ScT, soybean phase of the corn-soybean rotation and chisel tillage; SSSNT, continuous soybean and no-till; SSST, continuous soybean and chisel tillage.

Table 3. Community structure ( $\beta$-diversity) measures for fungi following 20 years of crop rotation and tillage treatments, and their interaction, based on pairwise permanova computation of weighted unifrac distances. The pseudo-F column represents the comparison between UniFrac distances for a given treatment combination (listed in the Treatments Compared column). The $p$-value and q-value columns indicate the probability of type I and type II errors associated with the treatment comparisons, respectively.

\begin{tabular}{|c|c|c|c|c|c|}
\hline Treatment & Treatments Compared & Sample Size & Pseudo-F & $p$-Value & q-Value \\
\hline \multirow{6}{*}{ Rotation $^{+}$} & CCC-Cs & 94 & 1.83 & 0.0270 & 0.0324 \\
\hline & CCC-SSS & 95 & 3.68 & 0.0010 & 0.0060 \\
\hline & CCC-Sc & 95 & 2.12 & 0.0150 & 0.0225 \\
\hline & Cs-SSS & 95 & 2.21 & 0.0070 & 0.0200 \\
\hline & Cs-Sc & 95 & 1.95 & 0.0100 & 0.0200 \\
\hline & SSS-Sc & 96 & 1.35 & 0.1250 & 0.1250 \\
\hline Tillage $\ddagger$ & NT-T & 190 & 1.63 & 0.0450 & 0.0450 \\
\hline
\end{tabular}


Table 3. Cont.

\begin{tabular}{|c|c|c|c|c|c|}
\hline Treatment & Treatments Compared & Sample Size & Pseudo-F & $p$-Value & q-Value \\
\hline \multirow{28}{*}{ Rotation $\times$ Tillage ${ }^{\bullet}$} & CCCNT-CCCT & 47 & 1.25 & 0.1870 & 0.2277 \\
\hline & CCCNT-CsNT & 48 & 1.26 & 0.1630 & 0.2075 \\
\hline & CCCNT-CsT & 47 & 1.87 & 0.0300 & 0.0700 \\
\hline & CCCNT-SSSNT & 48 & 2.61 & 0.0020 & 0.0280 \\
\hline & CCCNT-SSST & 48 & 2.13 & 0.0280 & 0.0700 \\
\hline & CCCNT-ScNT & 48 & 1.57 & 0.0780 & 0.1456 \\
\hline & CCCNT-ScT & 48 & 1.85 & 0.0290 & 0.0700 \\
\hline & CCCT-CsNT & 47 & 1.32 & 0.1310 & 0.1747 \\
\hline & CCCT-CsT & 46 & 1.35 & 0.1210 & 0.1747 \\
\hline & CCCT-SSSNT & 47 & 3.22 & 0.0010 & 0.0280 \\
\hline & CCCT-SSST & 47 & 2.20 & 0.0120 & 0.0700 \\
\hline & CCCT-ScNT & 47 & 1.60 & 0.0610 & 0.1220 \\
\hline & CCCT-ScT & 47 & 1.70 & 0.0270 & 0.0700 \\
\hline & CsNT-CsT & 47 & 0.88 & 0.5910 & 0.6129 \\
\hline & CsNT-SSSNT & 48 & 1.69 & 0.0250 & 0.0700 \\
\hline & CsNT-SSST & 48 & 1.41 & 0.1120 & 0.1742 \\
\hline & CsNT-ScNT & 48 & 1.11 & 0.2710 & 0.3035 \\
\hline & CsNT-ScT & 48 & 1.75 & 0.0210 & 0.0700 \\
\hline & CsT-SSSNT & 47 & 1.89 & 0.0140 & 0.0700 \\
\hline & CsT-SSST & 47 & 1.76 & 0.0390 & 0.0840 \\
\hline & CsT-ScNT & 47 & 1.42 & 0.0950 & 0.1663 \\
\hline & CsT-ScT & 47 & 1.82 & 0.0300 & 0.0700 \\
\hline & SSSNT-SSST & 48 & 1.40 & 0.1260 & 0.1747 \\
\hline & SSSNT-ScNT & 48 & 0.95 & 0.5040 & 0.5428 \\
\hline & SSSNT-ScT & 48 & 2.34 & 0.0070 & 0.0653 \\
\hline & SSST-ScNT & 48 & 0.78 & 0.7060 & 0.7060 \\
\hline & SSST-ScT & 48 & 1.48 & 0.1050 & 0.1729 \\
\hline & ScNT-ScT & 48 & 1.18 & 0.2230 & 0.2602 \\
\hline
\end{tabular}

${ }^{\dagger} \mathrm{CCC}$, continuous corn; Cs, corn phase of the corn-soybean rotation; Sc, soybean phase of the corn-soybean rotation; SSS, continuous soybean. $\ddagger_{\mathrm{N} T}$, no-till; T, chisel tillage. ' $\mathrm{CCCNT}$, continuous corn, and no-till; CCCT, continuous corn, and chisel tillage; CsNT, corn phase of the corn-soybean rotation and no-till; CsT, corn phase of the corn-soybean rotation and chisel tillage; ScNT, soybean phase of the corn-soybean rotation and no-till; ScT, soybean phase of the corn-soybean rotation and chisel tillage; SSSNT, continuous soybean and no-till; SSST, continuous soybean and chisel tillage.

Table 4. Community structure ( $\beta$-diversity) measures for archaea following 20 years of crop rotation and tillage treatments, and their interaction, based on pairwise permanova computation of weighted unifrac distances. The pseudo-F column represents the comparison between UniFrac distances for a given treatment combination (listed in the Treatments Compared column). The $p$-value and q-value columns indicate the probability of type I and type II errors associated with the treatment comparisons, respectively.

\begin{tabular}{|c|c|c|c|c|c|}
\hline Treatment & Treatments Compared & Sample Size & Pseudo-F & $p$-Value & q-Value \\
\hline \multirow{6}{*}{ Rotation $^{+}$} & CCC-Cs & 85 & 2.49 & 0.0620 & 0.1240 \\
\hline & CCC-SSS & 89 & 7.08 & 0.0010 & 0.0060 \\
\hline & $\mathrm{CCC}-\mathrm{Sc}$ & 89 & 0.97 & 0.3270 & 0.3270 \\
\hline & Cs-SSS & 88 & 1.56 & 0.1610 & 0.2415 \\
\hline & Cs-Sc & 88 & 1.25 & 0.2320 & 0.2784 \\
\hline & SSS-Sc & 92 & 5.24 & 0.0040 & 0.0120 \\
\hline Tillage $\ddagger$ & NT-T & 177 & 2.17 & 0.0920 & 0.0920 \\
\hline
\end{tabular}


Table 4. Cont.

\begin{tabular}{|c|c|c|c|c|c|}
\hline Treatment & Treatments Compared & Sample Size & Pseudo-F & $p$-Value & q-Value \\
\hline \multirow{28}{*}{ Rotation $\times$ Tillage $\bullet$} & CCCNT-CCCT & 43 & 1.20 & 0.2790 & 0.4595 \\
\hline & CCCNT-CsNT & 41 & 1.02 & 0.3590 & 0.5026 \\
\hline & CCCNT-CsT & 43 & 3.15 & 0.0310 & 0.1085 \\
\hline & CCCNT-SSSNT & 44 & 3.49 & 0.0220 & 0.1085 \\
\hline & CCCNT-SSST & 44 & 4.71 & 0.0030 & 0.0840 \\
\hline & CCCNT-ScNT & 43 & 0.65 & 0.5930 & 0.6642 \\
\hline & CCCNT-ScT & 45 & 1.73 & 0.1300 & 0.2595 \\
\hline & CCCT-CsNT & 42 & 0.85 & 0.4010 & 0.5347 \\
\hline & CCCT-CsT & 44 & 2.73 & 0.0520 & 0.1456 \\
\hline & CCCT-SSSNT & 45 & 3.51 & 0.0270 & 0.1085 \\
\hline & CCCT-SSST & 45 & 4.50 & 0.0130 & 0.1085 \\
\hline & CCCT-ScNT & 44 & 0.80 & 0.4480 & 0.5702 \\
\hline & CCCT-ScT & 46 & 1.03 & 0.3140 & 0.4884 \\
\hline & CsNT-CsT & 42 & 1.71 & 0.1270 & 0.2595 \\
\hline & CsNT-SSSNT & 43 & 1.83 & 0.1050 & 0.2450 \\
\hline & CsNT-SSST & 43 & 2.78 & 0.0480 & 0.1456 \\
\hline & CsNT-ScNT & 42 & 0.59 & 0.6570 & 0.7075 \\
\hline & CsNT-ScT & 44 & 0.53 & 0.7680 & 0.7680 \\
\hline & CsT-SSSNT & 45 & 0.55 & 0.7190 & 0.7456 \\
\hline & CsT-SSST & 45 & 0.69 & 0.5480 & 0.6393 \\
\hline & CsT-ScNT & 44 & 3.01 & 0.0310 & 0.1085 \\
\hline & CsT-ScT & 46 & 1.19 & 0.2640 & 0.4595 \\
\hline & SSSNT-SSST & 46 & 0.76 & 0.5050 & 0.6148 \\
\hline & SSSNT-ScNT & 45 & 3.26 & 0.0230 & 0.1085 \\
\hline & SSSNT-ScT & 47 & 1.76 & 0.1390 & 0.2595 \\
\hline & SSST-ScNT & 45 & 4.95 & 0.0130 & 0.1085 \\
\hline & SSST-ScT & 47 & 2.45 & 0.0610 & 0.1553 \\
\hline & ScNT-ScT & 46 & 1.02 & 0.3450 & 0.5026 \\
\hline
\end{tabular}

${ }^{\dagger}$ CCC, continuous corn; Cs, corn phase of the corn-soybean rotation; Sc, soybean phase of the corn-soybean rotation; SSS, continuous soybean. $\ddagger$ NT, no-till; T, chisel tillage. ${ }^{\bullet}$ CCCNT, continuous corn, and no-till; CCCT, continuous corn, and chisel tillage; CsNT, corn phase of the corn-soybean rotation and no-till; CsT, corn phase of the corn-soybean rotation and chisel tillage; ScNT, soybean phase of the corn-soybean rotation and no-till; ScT, soybean phase of the corn-soybean rotation and chisel tillage; SSSNT, continuous soybean and no-till; SSST, continuous soybean and chisel tillage.

\subsection{Statistical Analysis}

In order to identify the responsive microbes and estimate treatment effects, the relative abundances (RAs, \%) of each ASV were examined. [As described in Kim, Zabaloy, Riggins, Rodríguez-Zas, and Villamil [23]] Using the JMP ${ }^{\circledR}$ predictor screening platform based on bootstrap forest partitioning [38,39] on the original dataset, a condensed set of responsive microbes was produced. The responsive dataset consisted of 35 out of 4098 bacterial ASVs, 37 out of 390 fungal ASVs, and 11 out of 28 archaeal ASVs. These responsive microbes contributed to at least $1 \%$ of the variability in the model algorithms (Tables S3-S5). Then, the responsive microbe ASVs for each taxon were analyzed by principal component analysis (PCA) to further remove redundancy and avoid multicollinearity issues. Next, the RAs of these ASVs were summarized into a set of uncorrelated, orthogonal

Bacterial RAs for the phyla level showed that Proteobacteria (30\%) was the most abundant, followed by Acidobacteria (20\%), Actinobacteria (17\%), Chloroflexi (10\%), Planctomycetes $(10 \%)$, Bacteroidetes (7\%), Rokubacteria (3\%), and Verrucomicrobia (3\%) variables called principal components (PCs) utilizing the FACTOR procedure in SAS (v 9.4 SAS Institute, Cary, NC). The PCs with eigenvalues $\geq 1$ that explained $>5 \%$ of the variability in the dataset were then used as independent variables for further analysis. The ASVs with PC loading values $>|0.5|$ were considered significant and classified as responsive microbes [40]. Using the GLIMMIX procedure in SAS, linear mixed models were fit to each responsive variable, including the $\alpha$-diversity measures (Table 1 ) and PC scores of top contributing ASVs. Crop rotation and tillage were considered fixed effects, whereas 
blocks and years were considered random terms in the analyses of variance. Using SAS, least-square means of the response variables were separated by treatment levels and interactions, using the pdiff option and setting the probability of a type I error at $\alpha=0.05$. SigmaPlot was used to visualize the RA responses for each significant effect between the PC scores and treatments. The figures presented in the results characterized the combined PCA results and associated means separations for indicator taxa ASVs based on their RAs (the complete list of indicator microbes within each PC by taxa is shown in Tables S3-S5). The calculations displayed in those figures were the mean PC score for a given treatment multiplied by the PC loading score for the listed ASVs; error bars represented the standard error of the mean for each PC score by treatment multiplied by the absolute value of each ASV loading. Calculations for $\beta$-diversity, which used weighted UniFrac distance, were conducted by QIIME2 using pairwise PERMANOVA (permutational multivariate analysis of variance) for comparing differences between treatment levels by pseudo-F test statistics and their $p$ - and q-values, which represented the expected false positive (p) and negative rates (q) in multiple hypothesis testing [41,42].

\section{Results}

\subsection{Overall Characterization of Soil Indicator Microbes}

The bacterial kingdom had 47,888,681 16S V4 region sequences clustered into 4098 ASVs. The fungal kingdom had 5,253,422 ITS region sequences clustered into 390 ASVs. The archaeal kingdom had 2,380,099 archaeal 16S rRNA region sequences clustered into 28 ASVs. The $\alpha$-diversity measurements (ASV counts, Pielou, and $\mathrm{H}^{\prime}$ ) for bacteria and archaea revealed no statistical differences for the main effects of crop rotation and tillage (Table 1). However, fungi showed CCC having statistically greater ASV counts and $\mathrm{H}^{\prime}$ measurements ( $p=0.01$ and 0.03 , respectively) compared to SSS, with the rotated corn and soybean treatments being not different from either monoculture.

The analysis for $\beta$-diversity in the bacterial kingdom structure differed significantly $(p<0.01)$ for 26 out of the 28 rotation by tillage interactions, the exceptions being CsNTScNT and CsT-ScT (Table 4). The $\beta$-diversity in the fungal kingdom structure differed significantly for 13 out of the 28 treatment interactions, most of which were comparisons between corn and soybean phases (Table 3). The $\beta$-diversity measurements for the archaeal domain structure differed significantly for 9 out of the 28 treatment interactions, with 8 of the 9 comparisons driven by the monocultures (Table 4).

(Table S2). The fungal community was dominated completely by the phylum Ascomycota $(100 \%)$, of which seven out of the eight indicator species came from the class Sordariomycetes (Table S3). The indicator species for the archaeal community were nearly all from the phylum Thaumarchaeota $(73 \%)$, followed by Euryarchaeota $(18 \%)$ and Nanoarchaeaeota (9\%) (Table S5).

\subsection{ASVs Responses to Crop Rotation and Tillage Treatments}

\subsubsection{Bacteria}

The PCA on the 16S V4 bacterial domain produced five PCs (PC1-PC5; Table 5 and Table S3), explaining $65 \%$ of the variability in the 35 selected top-contributing ASVs. Within each PC, bacterial indicator microbes were flagged when significant correlations (loadings $\geq 1|0.5|$ ) were detected. The taxonomic classification of these ASVs provided by the SILVA database is listed in Table S3. 


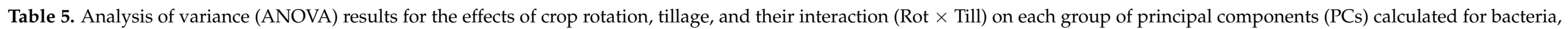

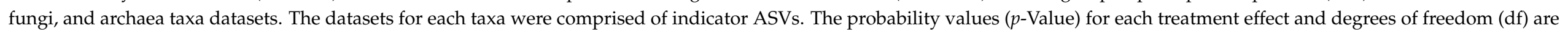

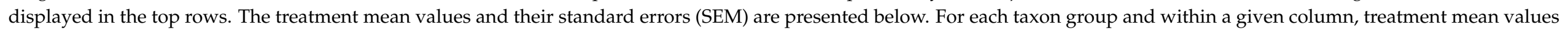
followed by the same lowercase letter were not statistically different $(\alpha=0.05)$.

\begin{tabular}{|c|c|c|c|c|c|c|c|c|c|c|c|c|c|c|c|c|}
\hline & & \multicolumn{5}{|c|}{ Bacteria } & \multicolumn{5}{|c|}{ Fungi } & \multicolumn{5}{|c|}{ Archaea } \\
\hline & & PC1 & PC2 & PC3 & PC4 & PC5 & PC1 & PC2 & PC3 & PC4 & PC5 & PC1 & PC2 & PC3 & PC4 & PC5 \\
\hline Treatments & df & \multicolumn{5}{|c|}{$p$-Value } & \multicolumn{5}{|c|}{$p$-Value } & \multicolumn{5}{|c|}{$p$-Value } \\
\hline Rotation & 3 & 0.00 & 0.01 & 0.18 & 0.29 & 0.19 & 0.02 & 0.42 & 0.47 & 0.83 & 0.61 & 0.01 & 0.20 & 0.98 & 0.95 & 0.39 \\
\hline Tillage & 1 & 0.00 & 0.01 & 0.02 & 0.00 & 0.00 & 0.79 & 0.37 & 0.00 & 0.11 & 0.03 & 0.16 & 0.26 & 0.05 & 0.00 & 0.09 \\
\hline Rot $\times$ Till & 3 & 0.31 & 0.01 & 0.01 & 0.68 & 0.06 & 0.09 & 0.79 & 0.04 & 0.70 & 0.66 & 0.15 & 0.39 & 0.79 & 0.21 & 0.55 \\
\hline \multicolumn{17}{|c|}{ Treatment means } \\
\hline $\mathrm{CCC}^{+}$ & & $-1.13 \mathrm{a}$ & 0.51 & 0.29 & -0.23 & -0.01 & $1.21 \mathrm{a}$ & -0.12 & 0.07 & 0.24 & 0.13 & $-0.73 c$ & 0.09 & 0.02 & -0.05 & -0.52 \\
\hline Cs & & $-0.14 b$ & -1.69 & -0.03 & 0.00 & -0.61 & $-0.06 \mathrm{~b}$ & 0.64 & 0.20 & -0.29 & 0.07 & $0.10 \mathrm{ab}$ & 0.32 & 0.03 & -0.08 & 0.30 \\
\hline Sc & & 0.17 b & -0.55 & 0.12 & -0.29 & 0.52 & $-0.11 b$ & -0.39 & -0.09 & -0.02 & -0.31 & $-0.04 b$ & -0.41 & -0.12 & 0.06 & 0.11 \\
\hline SSS & & $1.09 \mathrm{c}$ & 0.21 & -0.38 & 0.52 & 0.10 & $-1.04 \mathrm{c}$ & -0.13 & -0.18 & 0.07 & 0.11 & $0.67 \mathrm{a}$ & 0.00 & 0.07 & 0.07 & 0.11 \\
\hline SEM & & 0.29 & 0.33 & 0.52 & 0.68 & 0.37 & 0.18 & 0.41 & 0.33 & 0.42 & 0.42 & 0.40 & 0.34 & 0.38 & 0.29 & 0.36 \\
\hline $\mathrm{NT} \ddagger$ & & $-0.25 \mathrm{a}$ & -0.29 & -0.25 & $-0.19 a$ & $0.43 \mathrm{a}$ & -0.02 & 0.10 & -0.57 & 0.19 & $-0.30 \mathrm{a}$ & -0.11 & -0.14 & $-0.28 \mathrm{a}$ & $-0.35 \mathrm{a}$ & -0.19 \\
\hline $\mathrm{T}$ & & $0.25 b$ & 0.29 & 0.25 & $0.19 \mathrm{~b}$ & $-0.43 b$ & 0.02 & -0.10 & 0.57 & -0.19 & $0.30 \mathrm{~b}$ & 0.11 & 0.14 & $0.28 \mathrm{~b}$ & $0.35 \mathrm{~b}$ & 0.19 \\
\hline SEM & & 0.25 & 0.30 & 0.50 & 0.63 & 0.30 & 0.13 & 0.25 & 0.30 & 0.25 & 0.38 & 0.36 & 0.30 & 0.27 & 0.24 & 0.23 \\
\hline $\mathrm{CCC}^{-\mathrm{NT}} \bullet^{\bullet}$ & & -1.34 & $0.72 \mathrm{ab}$ & $-0.59 b$ & -0.42 & 0.85 & 0.97 & 0.04 & $-0.81 \mathrm{~d}$ & 0.41 & -0.29 & -0.96 & -0.03 & -0.17 & -0.81 & -0.50 \\
\hline Cs-NT & & -0.30 & -0.27 cde & $-0.02 b$ & -0.28 & -0.31 & 0.02 & 0.86 & $-0.52 \mathrm{~cd}$ & -0.31 & -0.16 & 0.16 & 0.52 & -0.39 & -0.18 & -0.11 \\
\hline Sc-NT & & -0.23 & $-0.92 \mathrm{e}$ & $0.07 \mathrm{~b}$ & -0.36 & 0.93 & -0.27 & -0.28 & $-0.61 \mathrm{~cd}$ & 0.36 & -0.37 & -0.39 & -0.78 & -0.51 & -0.20 & -0.10 \\
\hline SSS-NT & & 0.87 & $-0.69 \mathrm{de}$ & $-0.48 b$ & 0.28 & 0.27 & -0.79 & -0.21 & $-0.34 \mathrm{~cd}$ & 0.29 & -0.37 & 0.74 & -0.25 & -0.05 & -0.23 & -0.05 \\
\hline Cs-T & & 0.03 & $-0.07 \mathrm{bcd}$ & $-0.04 b$ & 0.28 & -0.91 & -0.13 & 0.43 & $0.91 \mathrm{a}$ & -0.27 & 0.30 & 0.04 & 0.13 & 0.44 & 0.01 & 0.72 \\
\hline Sc-T & & 0.57 & -0.19 cde & $0.17 \mathrm{~b}$ & -0.22 & 0.11 & 0.04 & -0.50 & $0.43 \mathrm{ab}$ & -0.40 & -0.25 & 0.31 & -0.05 & 0.27 & 0.31 & 0.32 \\
\hline SSS-T & & 1.31 & $1.12 \mathrm{a}$ & $-0.28 b$ & 0.75 & -0.08 & -1.28 & -0.04 & $-0.02 \mathrm{bc}$ & -0.15 & 0.59 & 0.60 & 0.24 & 0.19 & 0.37 & 0.28 \\
\hline SEM & & 0.30 & 0.39 & 0.55 & 0.69 & 0.41 & 0.23 & 0.47 & 0.37 & 0.48 & 0.50 & 0.43 & 0.41 & 0.46 & 0.37 & 0.41 \\
\hline
\end{tabular}

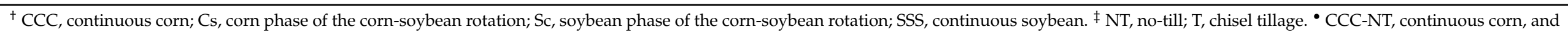

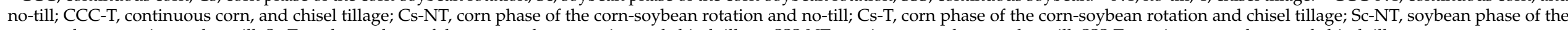
corn-soybean rotation and no-till; Sc-T, soybean phase of the corn-soybean rotation and chisel tillage; SSS-NT, continuous soybean and no-till; SSS-T, continuous soybean and chisel tillage. 
PC1 explained 36\% of the variability, which contained significant loadings from 23 ASVs by the most explanatory taxonomic rank (listed in parenthesis: P, phylum; C, class; O, order; F, family; G, genus; S, species) (Table S2). Positive loadings for PC1 were detected from Paludibaculum (G), Pyrinomonadaceae (F), Holophagae (C), Acidobacteria (P), Actinomarinales (O), Actinomycetales $(\mathrm{O})$, Actinobacterium $(\mathrm{O})$, Anaerolineae $(\mathrm{C})$, Dehalococcoidia (C), Planctomycetes (P), Phycisphaerae (C), Nordella (G), Betaproteobacteriales $(\mathrm{O})$, and Rokubacteriales $(\mathrm{O})$. Negative loadings from PC1 were from Acidobacteriaceae (Subgroup 1) (F), Candidatus Solibacter (S), Microbacteriaceae (F), Ktedonobacterales (O), Tepidisphaerales (O), Micropepsaceae (F), Chujaibacter (G), Rhodanobacter (G), and Pedosphaerales (O). PC2 explained $9 \%$ of the variability and saw only two negative loadings from Chitinophagales $(\mathrm{O})$ and Nitrosomonadaceae $(\mathrm{F})$. PC3 explained $8 \%$ of the variability and had positive loadings from Sphingobacteriales $(\mathrm{O})$ and Gammaproteobacteria $(\mathrm{C})$ and one negative loading from Gaiella $(\mathrm{G})$. PC4 explained $6 \%$ of the variability and contained one positive loading from Archangiaceae (F). PC5 explained 6\% of the variability and contained one negative loading from Luteimonas $(\mathrm{G})$.

The results from the bacterial ANOVA (Table 5) detected significant main effects for crop rotation and tillage $(p=0.0001)$ from PC1 (Figure 1) and just tillage effects for PC4 ( $p=0.0041)$ and PC5 ( $p=0.0001)$ (Figure 2). In PC1, the means separation procedure showed that treatment mean PC scores from SSS were significantly greater than the other three treatments and rotated corn and soybean being greater than CCC. In PC4, the means for tillage were found to be greater than no-till. PC2 $(p=0.006)$ and PC3 $(p=0.0142)$ both saw a significant interaction between crop rotation and tillage (Figure 2 ). The interaction in PC2 showed an intricate interaction with SSST having the greatest mean but not different from CCCNT and CCCT; the rotated treatments were not different and were generally the lowest. The interaction for PC3, however, was more pronounced, with CCCT having the largest mean and all of the combinations being significantly lower but not different from each other (Figure 2).

\subsubsection{Fungi}

The PCA on the ITS fungal kingdom produced 5 PCs (PC1-PC5; Table 5 and Table S4), explaining a total of $34 \%$ of the variability in the 37 selected top-contributing fungal ASVs. As with bacteria, within each PC, fungal indicator species were flagged when significant correlations (loadings $\geq|0.5|$ ) were found and identified to the nearest classification as provided by the SILVA database; fungal classification specifics are listed in Table S4.

PC1 explained $8 \%$ of the variability and contained one significant positive loading from the ASV Fusarium sporotrichioides (S). PC2 explained 7\% of the variability and contained positive loadings from Mycosphaerellaceae (F), Gibellulopsis piscis (S), and Plectosphaerella (G). PC3 also explained 7\% of the variability and contained positive loadings from Coniochaetaceae (F), Schizothecium (G), and Schizothecium carpinicola (S). PC4 explained 6\% of the variability and contained a positive loading from Clonostachys rosea (S). PC5 explained $6 \%$ of the variability, however, no significant correlations (loadings $\geq|0.5|$ ) were selected.

The fungal ANOVA results (Table 5) found a significant crop rotation effect $(p=0.0163$ ) for PC1 and a tillage effect for PC5 ( $p=0.0348)$ (Figure 3). The means separation procedure for PC1 showed that CCC was the largest, the rotated treatments in the middle, and SSS having the lowest mean. The mean for NT was significantly lower than the mean for till in PC5, however, no indicator species was selected and thus will not be discussed further. A significant interaction between crop rotation and tillage $(p=0.0416)$ was detected for PC3. The interaction for PC3 was likely driven by a highly significant response of tillage, showing no-till being lower than till. This is confirmed by the greatest mean values occurring in CCCT, CsT, and ScT; the SSST treatment was not different from the NT pairs except for the CCCNT, which was the lowest overall (Figure 3). PC2 and PC4 contained no significant ANOVA findings and, therefore, will not be discussed further. 


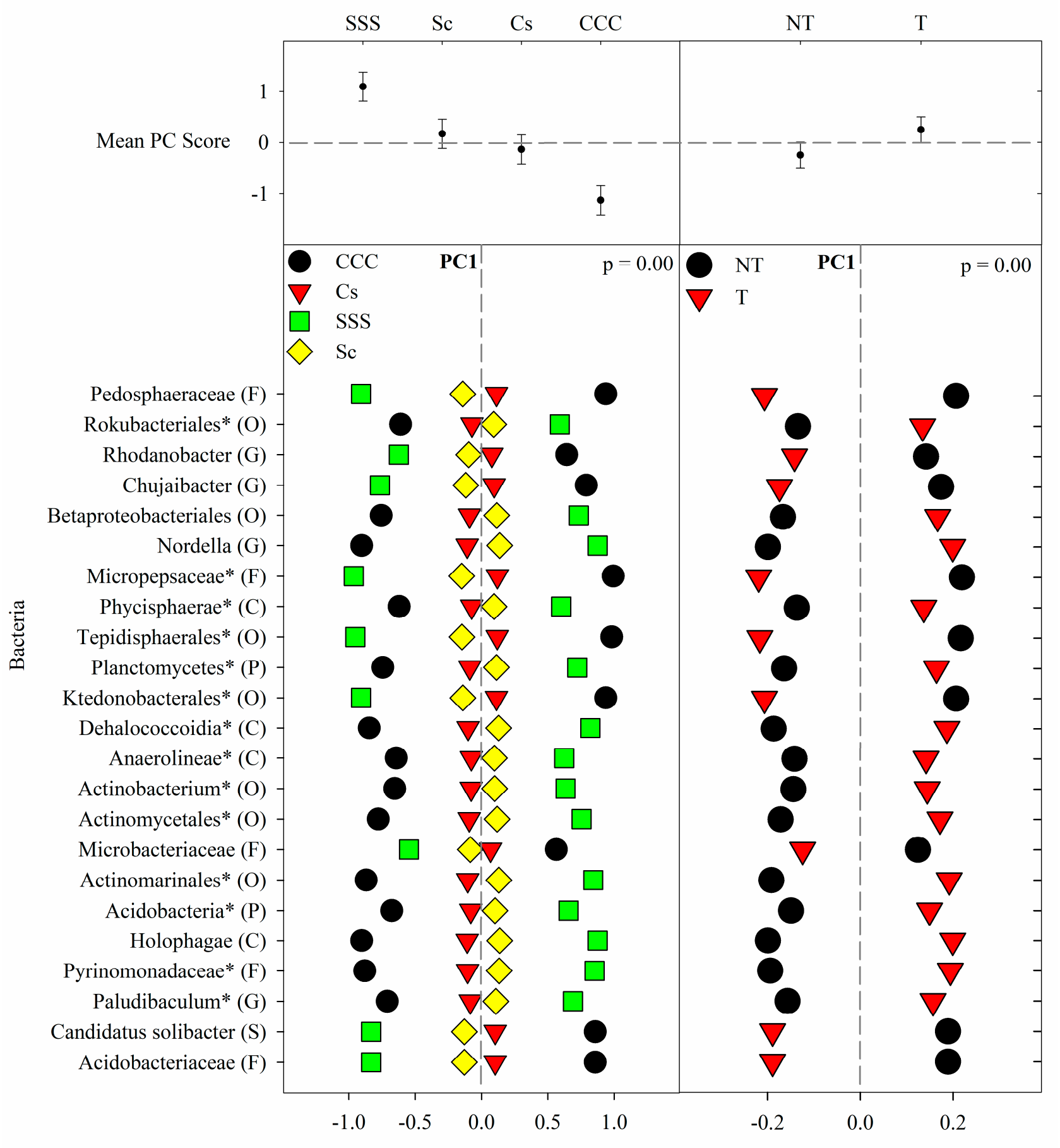

PC Scores

Figure 1. Mean bacterial principal component scores (PC) following 20 years of rotation and tillage treatments. Top panels show the bacterial mean PC score for both crop rotation and tillage main effects for PC1 based on the analysis of variance (ANOVA); error bars represent standard errors of the mean PC scores. Bottom panels show relative abundances (RAs) for each bacterial indicator ASVs by crop rotation and tillage effects. The main effects for PC1 are shown as CCC, continuous corn; Cs, corn phase of the corn-soybean rotation; Sc, soybean phase of the corn-soybean rotation; SSS, continuous soybean; NT, no-till; T, chisel tillage. For each taxon, the response of each ASV was calculated as the mean PC score multiplied by the PC loading score of a given ASV. The y-axes show the name of the ASV's most explanatory taxonomic rank in parentheses (P, phylum; C, class; O, order; F, family; G, genus; S, species). The "** after an ASV means it is uncultured. 


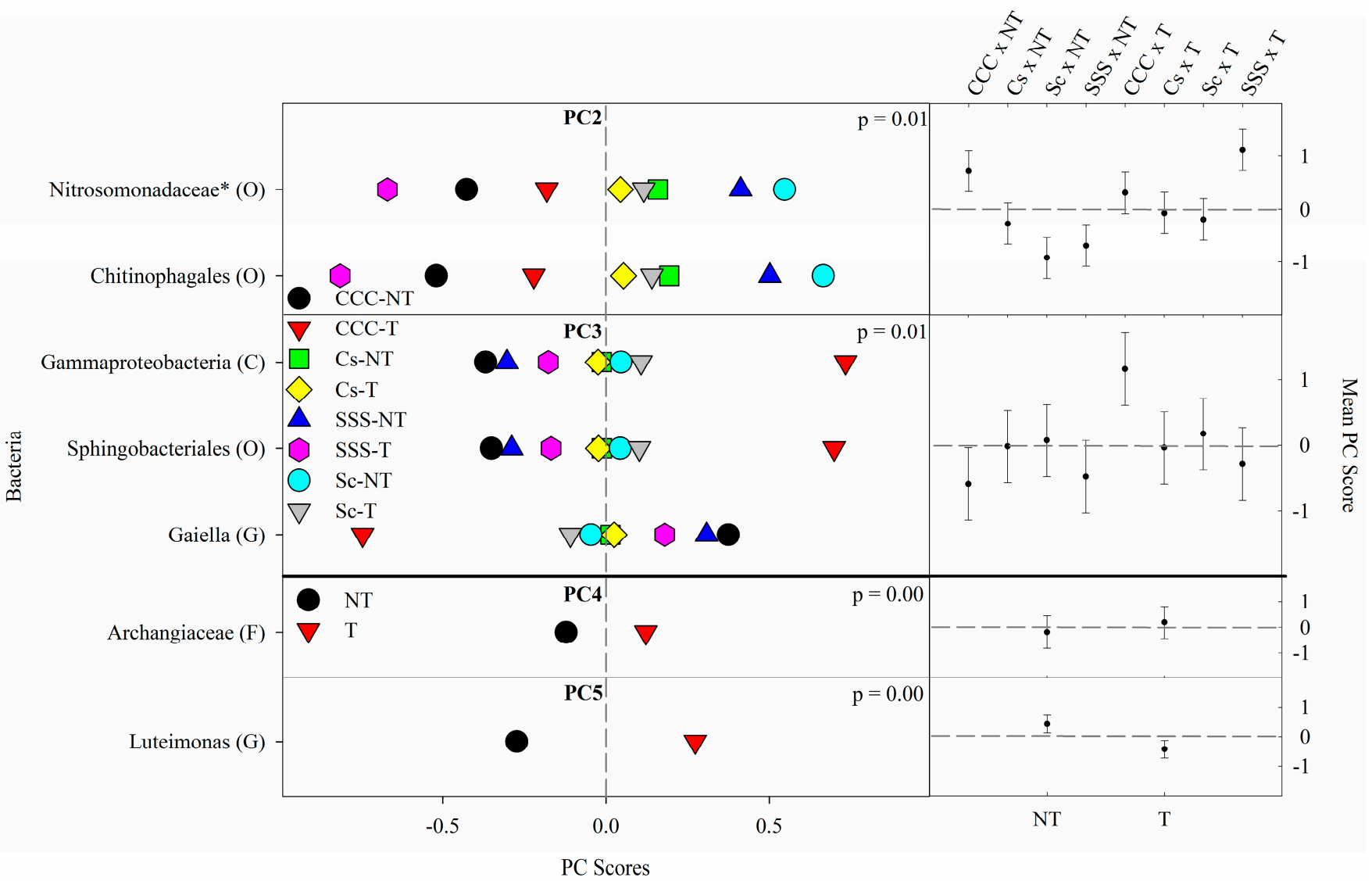

Figure 2. Mean bacterial principal component scores (PC) following 20 years of rotation and tillage treatments. Right panels show the bacterial mean PC score for the crop rotation $\times$ tillage interaction for PC2 and PC3 and a tillage effect for PC4 and PC5 based on the analysis of variance (ANOVA); error bars represent standard errors of the mean PC scores. Left panels show relative abundances (RAs) for each bacterial indicator ASVs by crop rotation $\times$ tillage and tillage. The crop rotation $\times$ tillage interaction for PC2 and PC3 is shown as CCC-NT, continuous corn, and no-till; CCC-T, continuous corn, and chisel tillage; Cs-NT, corn phase of the corn-soybean rotation and no-till; Cs-T, corn phase of the corn-soybean rotation and chisel tillage; Sc-NT, soybean phase of the corn-soybean rotation and no-till; Sc-T, soybean phase of the corn-soybean rotation and chisel tillage; SSS-NT, continuous soybean and no-till; SSS-T, continuous soybean and chisel tillage. The tillage main effect for PC4 and PC5 is shown as NT, no-till; T, chisel tillage. For each taxon, the response of each ASV was calculated as the mean PC score multiplied by the PC loading score of a given ASV. The y-axes show the name of the ASV's most explanatory taxonomic rank in parentheses (P, phylum; C, class; $\mathrm{O}$, order; $\mathrm{F}$, family; $\mathrm{G}$, genus; $\mathrm{S}$, species). The "** after an ASV means it is uncultured.

\subsubsection{Archaea}

The PCA on the 16S rRNA archaeal domain produced 5 PCs (PC1-PC5; Table 5 and Table S5), explaining a total of $69 \%$ of the variability in the 11 selected top-contributing archaeal ASVs. As with bacteria and fungi, archaeal indicator microbes were flagged when significant correlations (loadings $\geq 1|0.5|$ ) were discovered and identified by the SILVA database to the nearest classification; archaeal classification specifics are listed in Table S5.

PC1 explained 20\% of the variability and contained positive loadings from Candidatus Nitrocosmicus (S), Nitrososphaeraceae (F) (ammonia oxidizer), Nitrososphaeraceae (F); negative loadings came from Nitrososphaeraceae $(\mathrm{F})$ and Candidatus Nitrosotalea (S). PC2 explained $15 \%$ of the variability and contained negative loadings from two different Nitrososphaeraceae (F) families. PC3 explained 12\% of the variability and contained one positive loading from Woesearchaeia (C). PC4 explained 11\% of the variability and also contained one positive loading from Thermoplasmata (C). PC5 explained 10\% of the 
variability and contained opposing loadings, one positive from Thermoplasmata (C) and one negative from Candidatus Nitrososphaera (S).

The results from the ANOVA on the archaeal community found a crop rotation effect $(p=0.008)$ for PC1 (Figure 4). The means separation procedure showed that SSS was the largest but not different from Cs, which was not different from Sc; the CCC rotation was the lowest (Figure 4). Significant tillage main effects were detected for PC3 $(p=0.045)$ and PC4 ( $p=0.0032)$ with tillage being greater than no-till in both cases (Figure 4). PC2 and PC5 had no significant ANOVA findings and, therefore, will not be discussed further.

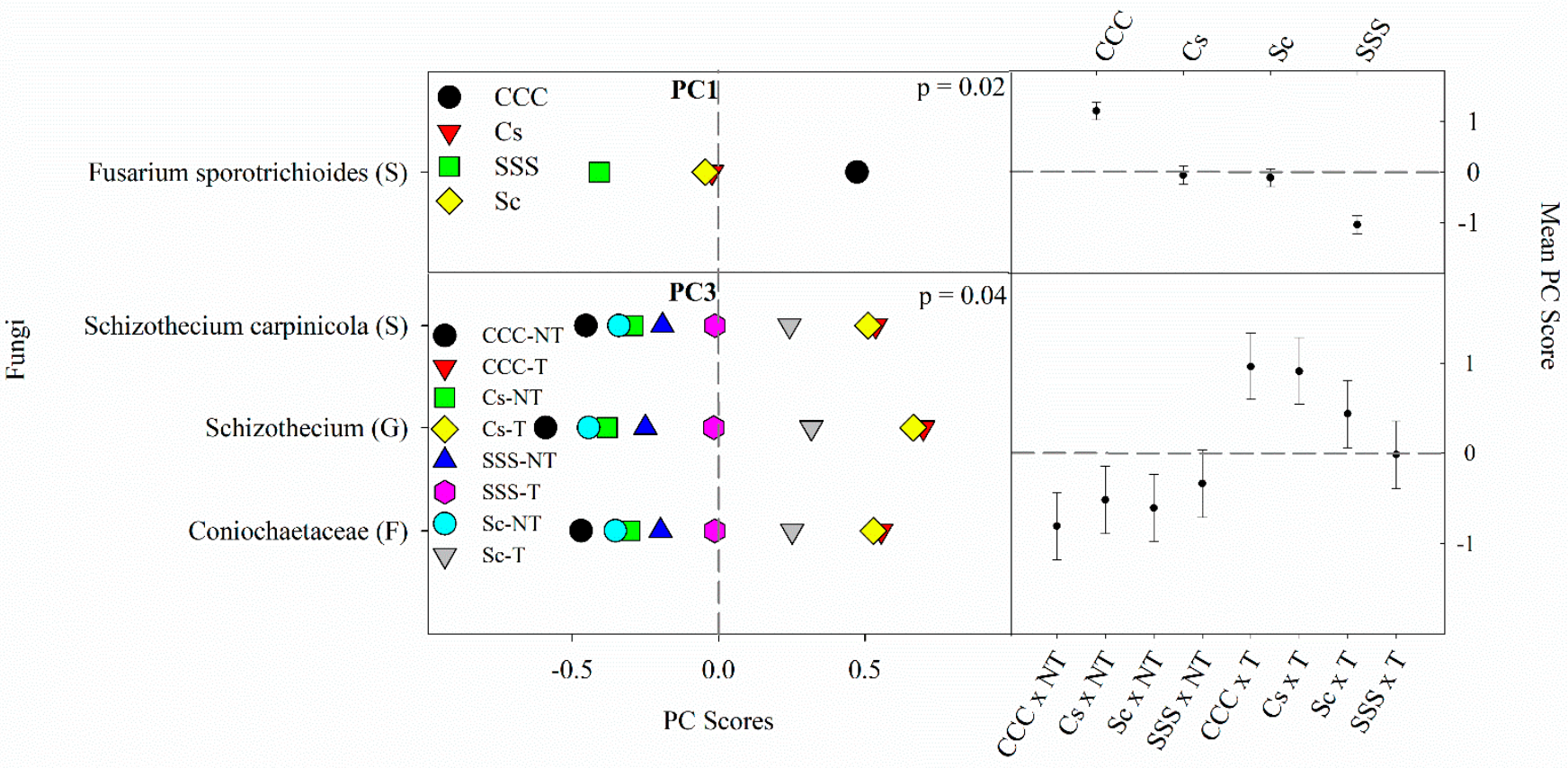

Figure 3. Mean fungal principal component scores (PC) following 20 years of rotation and tillage treatments. Right panels show the fungal mean PC score for the main effect of crop rotation for PC1 and the crop rotation $\times$ tillage interaction for PC3 based on the analysis of variance (ANOVA); error bars represent standard errors of the mean PC scores. Left panels show relative abundances (RAs) for each fungal indicator ASVs by crop rotation and crop rotation $\times$ tillage. The crop rotation main effects for PC1 are shown as CCC, continuous corn; Cs, corn phase of the corn-soybean rotation; Sc, soybean phase of the corn-soybean rotation; SSS, continuous soybean. The crop rotation $\times$ tillage interaction for PC3 is shown as CCC-NT, continuous corn and no-till; CCC-T, continuous corn, and chisel tillage; Cs-NT, corn phase of the corn-soybean rotation and no-till; Cs-T, corn phase of the corn-soybean rotation and chisel tillage; Sc-NT, soybean phase of the corn-soybean rotation and no-till; Sc-T, soybean phase of the corn-soybean rotation and chisel tillage; SSS-NT, continuous soybean and no-till; SSS-T, continuous soybean and chisel tillage. For each taxon, the response of each ASV was calculated as the mean PC score multiplied by the PC loading score of a given ASV. The y-axes show the name of the ASV's most explanatory taxonomic rank in parentheses ( $\mathrm{P}$, phylum; $\mathrm{C}$, class; $\mathrm{O}$, order; $\mathrm{F}$, family; $\mathrm{G}$, genus; $\mathrm{S}$, species). 


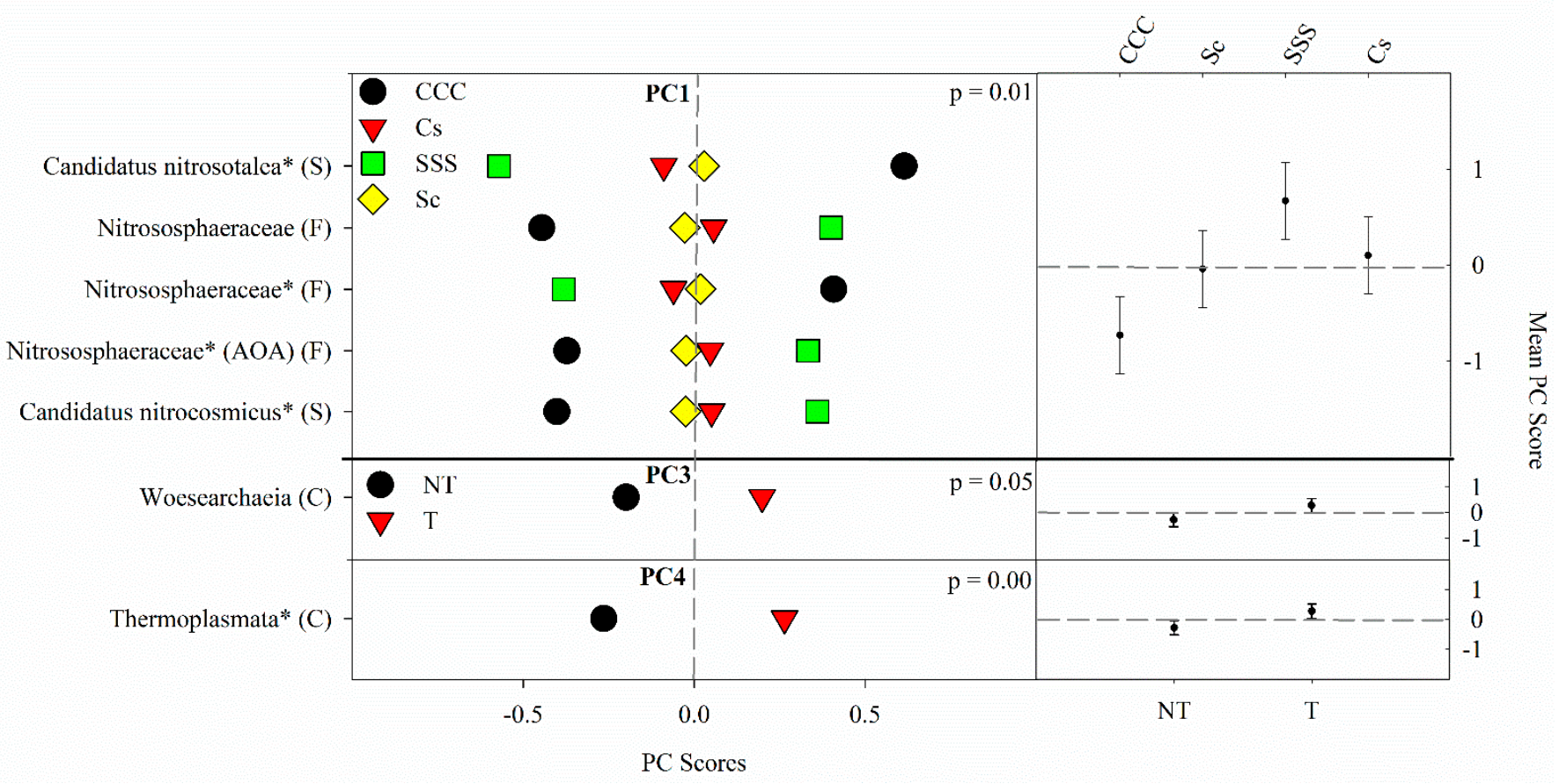

Figure 4. Mean archaeal principal component scores (PC) following 20 years of rotation and tillage treatments. Right panels show the archaeal mean PC score for the main effects of crop rotation for PC1 and tillage for PC3 and PC4 based on the analysis of variance (ANOVA); error bars represent standard errors of the mean PC scores. Left panels show relative abundances (RAs) for each archaeal indicator ASVs by crop rotation and tillage. The crop rotation main effects for PC1 are shown as CCC, continuous corn; Cs, corn phase of the corn-soybean rotation; Sc, soybean phase of the corn-soybean rotation; SSS, continuous soybean. The tillage effects for PC3 and PC4 are shown as NT, no-till; T, chisel tillage. For each taxon, the response of each ASV was calculated as the mean PC score multiplied by the PC loading score of a given ASV. The y-axes show the name of the ASV's most explanatory taxonomic rank in parentheses (P, phylum; C, class; O, order; F, family; G, genus; S, species). The “*” after an ASV means it is uncultured. AOA denotes ammonia-oxidizing archaea.

\section{Discussion}

Overall, the results from this study indicate that crop rotation and tillage affect soil microbial guilds significantly. The monocultures of corn and soybean had contrasting effects on microbial taxa, with the rotated crops showing intermediate effects. No-till and tillage also had contrasting effects, and like crop rotation, could be used to explain microbial indicators. Other studies also showed that CCC and SSS have contrasting effects on the soil indicator microbes, and the CS rotation having similar effects on both monocultures [1,2]. Crop rotation affects the quantity and quality of plant residues, which are the food source for microbes, resulting in functional changes performed by soil microbes; likewise, monocultures or crops requiring extensive pesticides affect microbial diversity and richness [1]. Chamberlain, Bolton, Cox, Suen, Conley, and Ané [2], too, found that crop residues were likely the driving factor in the community shifts between CCC and SSS, indicating that the quality of organic matter should be considered. Soman, Li, Wander, and Kent [15] observed that long-term crop rotation shifted microbial taxa into distinct communities based on the rotation. However, since the Morrow Plots are an extreme example of nutrient deficiencies, plots receiving manure or inorganic fertilizer generate more residues, leading to greater SOM and enhanced microbial diversity. Similarly, NT is likely to increase bacterial diversity compared to tilled systems by increasing SOM [21]; NT also enhances microbial biomass and enzymatic activity by creating a favorable microclimate [20]. Soil $\mathrm{pH}$ is also an important factor that affects community structure, which can be altered by fertilization $[43,44]$. Therefore, cropping systems, rotation or tillage, that significantly alter $\mathrm{SOM}$ and $\mathrm{pH}$ could be used to classify indicator microbes. 
The bacterial indicator microbes were categorized from seven different phyla and grouped by their responses to the treatments presented in this study. The CCC rotation is characterized as having high SOM due to large amounts of biomass returned annually, low soil $\mathrm{pH}$ due to $\mathrm{N}$ fertilization, elevated levels of nirK denitrification, and significantly greater levels of ammonia-oxidizing bacteria [25]. Thus in terms of N cycling, the CCC rotation was the most intense. The low soil $\mathrm{pH}$ was likely caused by the increased fertilizer rates compared to rotated corn $\left(246 \mathrm{~kg} \mathrm{~N} \mathrm{ha}^{-1}\right.$ vs. $\left.202 \mathrm{~kg} \mathrm{~N} \mathrm{ha}^{-1}\right)$ and receiving fertilizer yearly. Chamberlain, Bolton, Cox, Suen, Conley, and Ané [2] detected that soil pH and SOM explained the most variation, and like in our study, found that soil $\mathrm{pH}$ was lowest in the spring for CCC and SOM was the greatest from the CCC year-round. Ashworth, DeBruyn, Allen, Radosevich and Owens [1] also found that CCC had greater levels of C and $\mathrm{N}$ compared to a CS or SSS rotation and concluded that the inclusion of soybean into a crop rotation depletes soil organic $C$, which is a favored food source for microbes. Corn in general leaves behind about three times more residue than soybean following harvest [45] and has a higher $\mathrm{C}: \mathrm{N}$ ratio, making the residues take longer to decompose [46]. In our study, the NT treatment responded similarly to CCC (Figure 1). Expectedly, the RAs of indicator microbes showed similar responses to both crop rotation and tillage, where those increased with CCC also increased with NT. Given the use of SOM and pH to accurately identify treatment effects, we have grouped our bacterial indicator microbes in two groups: CCC and NT vs. SSS and T.

Thus, we have identified 12 bacterial ASVs with increased RAs from CCC and NT, or high SOM and low $\mathrm{pH}$ associated microbes, including Rhodanobacter (G), Chujaibacter $(\mathrm{G})$, Microbacteriaceae (F), Chitinophagales (O), Nitrosomonadaceae (F), Acidobacteriaceae (F), C. solibacter (S), Pedosphaeraceae (F), Micropepsaceae (F), Tepidisphaerales (O), Ktedonobacterales $(\mathrm{O})$, and Gaiella $(\mathrm{G})$ (Table S3). Rhodanobacter $(\mathrm{G})$ and Chujaibacter $(\mathrm{G})$ are both members of Rhodanobacteraceae (F) and have been found to be the second most unaffected by agricultural use [first being the Nitrosospira $(\mathrm{G})$ ] and negatively correlated to soil $\mathrm{pH}$ [24]. Rhodanbacter (G) was found to amplify the nirK denitrification gene [47,48]. Green, Prakash, Gihring, Akob, Jasrotia, Jardine, Watson, Brown, Palumbo, and Kostka [48] found that Rhodanobacter $(\mathrm{G})$ isolates accumulated nitrous oxide $\left(\mathrm{N}_{2} \mathrm{O}\right)$ during denitrification under their growing conditions; however, nos $\mathrm{Z}$ gene amplification was not observed. The relationship between increased nirK and accumulation of $\mathrm{N}_{2} \mathrm{O}$ likely translates into increased $\mathrm{N}_{2} \mathrm{O}$ emissions. This supposition was supported by Behnke, Zuber, Pittelkow, Nafziger, and Villamil [5], who showed that the CCC-T rotation by tillage combination, also taken from this study during 2012-2015, emits the most $\mathrm{N}_{2} \mathrm{O}$ compared to the other rotation by tillage combinations tested. Microbacteriaceae (F) are known to thrive under conditions of urea amendments and decreased $\mathrm{pH}$, which is explained by elevated RAs from the CCC rotation (Figure 1) and observed in Staley et al. [49] using microcosms of soil from corn and soybean trials comparing tillage and $\mathrm{N}$ rate. Chitinophagales $(\mathrm{O})$ is responsible for degrading organic matter [50] and is also associated with urea amendments and low $\mathrm{pH}$ [49]. Urea applications also increased the RAs for Nitrosomonadaceae (F) [49]. The low soil pH likely increased the RAs for Acidobacteriaceae (F) (Figure 1), which were enhanced in the CCC rotation. Other studies have observed increases in Acidobacteriaceae (F) as soil pH decreases [51-53]. Wang, et al. [54] found that C. solibacter (S) was strongly associated with low $\mathrm{pH}$ and contaminated sites suggesting that it might hold an ecological niche in such systems. Ward et al. [55] found that Acidobacteria (P) play a significant role in terrestrial C cycling, which would increase under chisel tillage. The CCC rotation, which also contains the largest levels of organic matter and crop residues [25], increased RAs from C. solibacter (S), which has been linked to increased levels of rice straw residue returned to the system and identified as a key species in the understanding of ecological processes from fertilized agroecosystems [56]. Pedosphaeraceae (F) have little information available but have been found in the soil and are thought to be associated with organic matter decomposition as they showed a positive correlation with Solibacteraceae (F) [57]. Micropepsaceae (F) information is scarce but has been found in acidic soils and is involved 
with carbon cycling [58]. Tepidisphaerales (O) has little information available except for an association with conventional farming [59], and WD2101(F) is polysaccharide degraders found in raised bogs and eutrophic fens [60]. Similarly, Ktedonobacterales $(\mathrm{O})$ is relatively unknown but have been found to inhabit forests, gardens, and sand in low numbers, as well as extreme environments, such as volcanoes and geothermal areas [61]. However, Neupane, Bulbul, Wang, Lehman, Nafziger, and Marzano [27] detected elevated Ktedonobacterales (O) levels from a CCC rotation, although little supporting information regarding their biological significance was found. The increased RAs from the CCC rotation and chisel tillage show that these resilient microbes are adapted to the harsh and acidic conditions in this treatment. Little is known about Gaiella $(\mathrm{G})$, aside from having a suspected relationship with plants and $C$ cycling traits similar to related species [62,63]. In general, the bacterial ASVs associated with CCC and NT, likely favor nutrient-rich environments and are copiotrophic.

Conversely, the SSS rotation is characterized as having low SOM due to high C:N ratio biomass and much less, in terms of amounts, compared to corn, closer to neutral soil $\mathrm{pH}$ due to no $\mathrm{N}$ fertilization, decreased levels of nirK denitrification, and significantly lower levels of ammonia-oxidizing bacteria [25] (Table S2). The chisel tillage treatment also has reduced levels of SOM due to quicker decomposition rates as tillage helps to increase residue surface area; likewise, chisel tillage incorporates fertilizer urea (in our case), leading to less surface soil acidification, as is the opposite in the NT treatment [25] (Table S2).

The 18 bacteria with increased RAs from SSS and T are grouped into what we are calling neutral $\mathrm{pH}$ and reduced fertilizer $\mathrm{N}$ associated microbes, including ASVs belonging to Rokubacteriales $(\mathrm{O})$, Phycisphaerae $(\mathrm{C})$, Planctomycetes $(\mathrm{P})$, Actinobacterium $(\mathrm{O})$, Actinomycetales $(\mathrm{O})$, Luteimonas $(\mathrm{G})$, Holophagae $(\mathrm{C})$, Acidobacteria $(\mathrm{P})$, Pyrinomonadaceae $(\mathrm{F})$, Paludibaculum $(\mathrm{G})$, Sphingobacteriales $(\mathrm{O})$, Archangiaceae $(\mathrm{F})$, Betaproteobacteriales $(\mathrm{O})$, Nordella (G), Dehalococcoidia (C), Anaerolineae (C), Actinomarinales (O), and Gammaproteobacteria (C). Rokubacteriales $(\mathrm{O})$ RAs were increased in the SSS rotation (decreased in the CCC rotation) in our study, which is in line with another study showing decreased RAs from corn samples compared to woodland samples, likely due to contrasting nutrient levels dictating microbial guild specializations, even within the same phyla [64]. Only one study reported Phycisphaerae (C) results but found that increased RAs were associated with the lower SOM and N level treatment [65]. Planctomycetes (P), specifically OM190 (C), was found to be a dominant microbe in a system with wheat (Triticum aestivum L.) and corn straw returned, no fertilizer added; the organic $C$ in this system was found to be significantly lower than the biomass + fertilizer treatments, however, soil $\mathrm{pH}$ was not different for any of the treatments but was near neutral (6.7-6.8) [66]. Actinobacterium $(O)$ and Actinomycetales $(\mathrm{O})$ are closely related and belong to MB-A2-108 (C) within Actinobacteria $(\mathrm{P})$; these microbes are capable of degrading a wide range of organic material and are known to thrive in nutrient scarce environments [67]. Shange et al. [68] found that Actinomycetales (O) showed the largest RAs from soils with the lowest SOM values; Actinomycetales $(\mathrm{O})$ is also an important member of the $\mathrm{N}$ cycling community [69]. Luteimonas $(\mathrm{G})$ growth occurs from $\mathrm{pH}$ 5-9, with optimal growth at $\mathrm{pH} 7.0$ [70]. Simmons, et al. [71] found Luteimonas (G) RAs were increased in unfertilized soil compared to soil amended with green waste compost. While Xiao et al. [72] found that Luteimonas (G) was positively correlated with soybean and alfalfa (Medicago sativa L.) biomass. Relatively little information exists for the Holophagae (C) Subgroup $7(\mathrm{O})$, except that RAs were found to be positively correlated with a legume treatment compared to grass [73], with $\mathrm{pH}$ [74], and negatively correlated to SOM [75]. Acidobacteria (P) and many of their subgroup RAs were negatively correlated to nutrient levels and associated with $C$ degradation [76]. Navarrete et al. [77] found that Subgroup 25 (C) was only found in soybean rhizospheric soil, not in their forest comparison site. Subgroup 25 (C) was also positively correlated to $\mathrm{pH}$ [78]. Pyrinomonadaceae (F) and Paludibaculum (G) both prefer only mildly acidic soils $[79,80]$, which explains the RA increases under the SSS rotation. Likewise, Pyrinomonadaceae (F) prefers complex proteinaceous substrates [79], and Paludibaculum (G) is unable to utilize nitrate and urea [80] 
as would be the case in the SSS rotation. Multiple studies have found that Sphingobacteriales $(\mathrm{O}) \mathrm{RAs}$ are negatively correlated to $\mathrm{N}$ fertilization [81-83]. Little information was available regarding Archangiaceae (F), but one study found that they are involved with the C cycle [84]. However, Myxococcales (O), the order for Archangiaceae (F), was found to be positively correlated with $\mathrm{pH}$ from agricultural lands, and RAs significantly increased from those under organic production [85]. Zhou et al. [86] also found a positive correlation between soil $\mathrm{pH}$ and Myxococcales (O) from forest and greenhouse soil. Furthermore, the authors discovered that bacterial community composition was a key factor in determining Myxococcales $(\mathrm{O})$ RAs since they are predatory bacteria. Betaproteobacteriales (O) TRA3-20 (F) has no information available and could be misclassified. However, some members of the Gammaproteobacteria $(\mathrm{C})$ are more abundant at neutral $\mathrm{pH}$ compared to acidic conditions [87]. Nordella (G), too, has little information available other than being more abundant at neutral to high soil $\mathrm{pH}$ [88]. Dehalococcoidia (C) are typically found in anaerobic conditions, but all grew best in neutral $\mathrm{pH}$ conditions with little growth in acidic conditions [89] and are known to be involved in C cycling [90]. Like Dehalococcoidia (C), Anaerolineae (C) is in the same phylum Chloroflexi and was also found to be associated with anaerobic conditions [91]. Yao et al. [92] found Anaerolineae (C) RAs declined as fertilizer $\mathrm{N}$ was introduced, though $\mathrm{pH}$ values were all above 8 . Near neutral $\mathrm{pH}$ requirements were also observed by Yamada et al. [93] and Kandasamy, Weerasuriya, White, Patterson, and Lazarovits [88]. Cai et al. [94] recently discovered that Anaerolineae (C) were involved in the denitrification step of the $\mathrm{N}$ cycle from wastewater treatment sludge, though more research is needed to confirm such findings in an agricultural setting. In a German barley study comparing low and high $\mathrm{N}$ rates and mouldboard plow tillage compared to conservation tillage, Actinomarinales (O) RAs were increased under the low $\mathrm{N}$ setting using a mouldboard plow [95]. Much of the published research for Actinomarinales (O) has taken place in aquatic environments, and they likely play a significant role in the global C cycle [96]. Gammaproteobacteria (C) R7C24 (O) was likely misclassified as there is no information available except for a finding in a diabetes medical trial [97]. Ultimately, the bacterial ASVs associated with SSS and tilled systems likely favor nutrient-poor environments and are oligotrophic.

All indicator microbes for the fungal kingdom belonged to Sordariomycetes (C). F. sporotrichioides (S) was the dominant fungi identified through our PCA, explaining $8 \%$ of the variability by this single species. F. sporotrichioides (S) is a common, ineffectual agricultural and grassland pathogen [98], commonly isolated from corn and other cereal crops [99]. F. sporotrichioides (S) RAs have been reported to be negatively associated with soil pH [100], as is the case in this study showing greater RAs from the CCC rotation, which has significantly lower $\mathrm{pH}$ compared to the other rotations [25]. Behnke, Zabaloy, Riggins, Rodriguez-Zas, Huang and Villamil [25] also found that fungal ITS gene copy numbers were increased in the CCC rotation compared to SSS. Predictably, the CCC rotation observed significantly greater ASVs and $\mathrm{H}^{\prime}$ compared to SSS (Table 1). Tillage is also an important management factor that affects fungal RAs; Coniochaetales (O) Coniochaetaceae (F) and both ASVs from Schizothecium $(\mathrm{G})$ are elevated from the tillage treatment as tillage is the driver of the significant interaction for PC3 (Figure 3). Larger Coniochaetales (O) RAs were observed in chisel-tilled wheat plots compared to NT [101] and also from the full tillage treatment from spring barley (Hordeum vulgare L.)-winter wheat-maize crop rotation [102]. Similarly, Schizothecium (G) RAs were increased in a standard tillage treatment compared to NT from a tomato (Solanum lycopersicum L.)-cotton (Gossypium arboretum L.) rotation [103] and also from a complex wheat-rapeseed (Brassica napus L.)-faba (Vicia faba L.) crop rotation [104]. Wang et al. [105] found that Schizothecium (G) RAs decreased in maize NT treatments. Sun et al. [106] studied three tillage treatments (moldboard plow, rotary tillage, and NT) and reported that fungal richness was significantly smaller in tilled systems compared to NT or reduced tillage. The increase of RAs in PC3 driven by tillage could indicate an adaption of these indicator fungi to disturbance, though more information would be needed to confirm. 
The indicator microbes for archaea were taken from three classes of indicator microbes and grouped according to their responses to the treatments in the study. C. Nitrosotalea (S) and an uncultured Nitrososphaeraceae (F) RAs were greater in the CCC rotation. C. Nitrosotalea (S) is an ammonia oxidizer found in acidic agricultural soil [107-110], which is the case in our study as the CCC rotation has the lowest pH. Lehtovirta-Morley, et al. [111] and Papadopoulou, Bachtsevani, Lampronikou, Adamou, Katsaouni, Vasileiadis, Thion, Menkissoglu-Spiroudi, Nicol, and Karpouzas [110] both confirmed that C. Nitrocosmicus (S) occupy contrasting ecological niches compared to C. Nitrosotalea (S) and C. Nitrocosmicus is present in larger RAs at neutral $\mathrm{pH}$. The unspecified AOA Nitrososphaeraceae $(\mathrm{F})$ showing elevated RAs from the SSS rotation matches Behnke, Zabaloy, Riggins, Rodriguez-Zas, Huang, and Villamil [25]. The authors found increased AOA gene copy numbers in the SSS rotation, however, since the archaea are mostly uncultured, that cannot be fully confirmed. Yu, Lawrence, Sooksa-nguan, Smith, Tenesaca, Howe, and Hall [56] found that typically Nitrososphaeraceae $(\mathrm{F})$ are $\mathrm{AOA}$ and positively associated with $\mathrm{pH}$, but the $\mathrm{pH}$ relationship depended on niche specialties of certain archaea. Woesearchaeia (C) and Thermoplasmata (C) Marine Group II are typically found in aquatic ecosystems [112-114]. However, Wang et al. [115] found both archaea ASVs in agricultural and estuarial soils, noting that the agricultural soils contained significantly greater abundance, richness, evenness, and diversity than freshwater or estuarine ecosystems. There is no information regarding tillage practices that influence the RAs for these archaea. Nevertheless, the tillage treatment had significantly greater surface $\mathrm{pH}$ [25] (Table S2), so $\mathrm{pH}$ could play a role in determining the RA for these two indicator archaea. Wang et al. [116] found that Woesearchaeia (C) was very abundant and negatively associated with salinity; while not a perfect relationship, typically the greater salinity, the lower the $\mathrm{pH}$.

\section{Conclusions}

This study adds valuable insight as to important microbes and how they respond to typical agricultural management. We found that bacterial indicator microbes responded contrastingly to the two monocultures with the rotated corn and soybean showing intermediate effects, partially confirming our hypothesis. Tillage, too, showed contrasting effects between chisel tillage and NT. Using those strong main effects, we grouped the indicator bacteria into organic matter dependent and acidophile vs. $\mathrm{N}$ adverse and neutrophile. This grouping agreed with our previous qPCR publication [25] and fit bacterial characterizations well. From the indicator bacteria, we found that many were involved in the $\mathrm{N}$ cycle and respond positively to conditions of increased inorganic N. Unlike bacteria, fewer fungi and archaea were selected as indicator microbes. Fungi were poorly identified, and all were from Sordariomycetes (C), with the top indicator species thriving in the low $\mathrm{pH}$ environment of CCC, confirming our hypothesis. The significant archaeal indicators were mainly AOA, preferring the neutral $\mathrm{pH}$ in the SSS rotation, though some AOA were found to be acidophile, partially confirming our hypothesis. This study shows the need to fully classify soil organisms to a finer level, which will help better understand the role specific microorganisms play in soil nutrient cycling. Future work should focus on identifying the uncultured yet significant ASVs described in this study. In addition, $\mathrm{N}$ cycle genetic analysis of these indicator species would greatly help explain their role in the agroecosystems. Using metagenomics and bioinformatics, we were able to select 49 indicator microbes out of thousands of ASVs from highly productive soils, using typical agronomic management practices from a replicated, long-term trial. These indicator taxa could potentially generate a soil assessment narrative to identify inefficiencies in agronomic practices or indicate possible environmental consequences.

Supplementary Materials: The following are available online at https://www.mdpi.com/article/10 $.3390 /$ microorganisms $9061244 /$ s1. Figure. S1: Rarefaction curves for the major kingdoms of bacteria (green; top panel), fungi (blue; middle panel), and archaea (red; bottom panel). Points show the average number of observed ASVs for a given sampling depth (x-axis). For each taxa, rarefaction curves plateaued at sampling depths of 35,100,10,000, and 1000 for bacterial, fungal, and archaeal 
sequences per sample, respectively. Table S1: Summary of field practices from Monmouth, Illinois from 1997-2016; dates are ranges that vary slightly year to year. Table S2: Principal component analysis of soil variables (17) for 0-10 cm soil depth with eigenvalues and cumulative proportion of the data set variability explained by the five principal components (PC) extracted with eigenvalues $>1$. Component correlation scores (eigenvectors) with loadings greater than $|0.5|$ are bolded. Probability values for the analysis of variance (ANOVA) and degrees of freedom (df) available for the effects of rotation I phase (Rotation), tillage (Tillage), and their interaction are shown for each extracted PCs. Table S3: List of bacterial principal components (PC) comprised by indicator species that contributed at least $5 \%$ of the variability in the data and with eigenvalue of at least 1 . Table S4: List of fungal principal components (PC) comprised by indicator species that contributed at least $5 \%$ of the variability in the data and with eigenvalue of at least 1. Table S5: List of archaeal principal components (PC) comprised by indicator species that contributed at least $5 \%$ of the variability in the data and with eigenvalue of at least 1 .

Author Contributions: Conceptualization, M.B.V. and M.C.Z.; methodology, G.D.B., N.K., C.W.R., M.C.Z. and S.R.-Z.; formal analysis, M.B.V., G.D.B. and S.R.-Z.; resources, M.B.V., S.R.-Z. and C.W.R.; data curation, M.B.V., M.C.Z., C.W.R., N.K. and G.D.B.; writing-original draft preparation, G.D.B. and M.B.V.; writing-review and editing, N.K., C.W.R., S.R.-Z. and M.C.Z.; supervision, project administration, and funding acquisition, M.B.V. All authors have read and agreed to the published version of the manuscript.

Funding: This research was partially funded by a HATCH Grant (No. ILLU-802-947) and by Award No. AG 2018-67019-27807 both from the United States Department of Agriculture, USDA-NIFA.

Institutional Review Board Statement: Not applicable.

Informed Consent Statement: Not applicable.

Data Availability Statement: The data presented in this study is available in the Mendeley Database at doi:10.17632/vjn8bf5fvy.2 (Available after 10 August 2021) [117].

Acknowledgments: We acknowledge Alvaro Hernandez and Mark Band from the Roy Carver Biotechnology Center for Functional Genomics lab at the University of Illinois at Urbana-Champaign for their assistance in creating the amplicon libraries. We are thankful to Greg Steckel, and Marty Johnson for their contribution in managing the experimental plots.

Conflicts of Interest: The authors declare that the research was conducted in the absence of any commercial or financial relationships that could be construed as a potential conflict of interest. The authors declare no conflict of interest.

\section{References}

1. Ashworth, A.; DeBruyn, J.; Allen, F.; Radosevich, M.; Owens, P. Microbial community structure is affected by cropping sequences and poultry litter under long-term no-tillage. Soil Biol. Biochem. 2017, 114, 210-219. [CrossRef]

2. Chamberlain, L.A.; Bolton, M.L.; Cox, M.S.; Suen, G.; Conley, S.; Ané, J.-M. Crop rotation, but not cover crops, influenced soil bacterial community composition in a corn-soybean system in southern Wisconsin. Appl. Soil Ecol. 2020, 154, 103603. [CrossRef]

3. Lal, R. Soil health and carbon management. Food Energy Secur. 2016, 5, 212-222. [CrossRef]

4. Schimel, J.P.; Schaeffer, S.M. Microbial control over carbon cycling in soil. Front. Microbiol. 2012, 3, 348. [CrossRef] [PubMed]

5. Behnke, G.D.; Zuber, S.; Pittelkow, C.M.; Nafziger, E.D.; Villamil, M.B. Long-term crop rotation and tillage effects on soil greenhouse gas emissions and crop production in Illinois, USA. Agric. Ecosyst. Environ. 2018, 261, 62-70. [CrossRef]

6. Gentry, L.; Ruffo, M.L.; Below, F.E. Identifying Factors Controlling the Continuous Corn Yield Penalty. Agron. J. 2013, 105, 295-303. [CrossRef]

7. Tariq, M.; Ali, H.; Hussain, N.; Nasim, W.; Mubeen, M.; Ahmad, S.; Hasanuzzaman, M. Fundamentals of Crop Rotation in Agronomic Management. In Agronomic Crops; Volume 1: Production Technologies; Hasanuzzaman, M., Ed.; Springer: Singapore, 2019; pp. 545-559.

8. Daigh, A.L.; Dick, W.A.; Helmers, M.J.; Lal, R.; Lauer, J.G.; Nafziger, E.; Pederson, C.H.; Strock, J.; Villamil, M.; Mukherjee, A.; et al. Yields and yield stability of no-till and chisel-plow fields in the Midwestern US Corn Belt. Field Crop. Res. 2018, 218, 243-253. [CrossRef]

9. Halvorson, A.D.; Mosier, A.R.; Reule, C.A.; Bausch, W.C. Nitrogen and Tillage Effects on Irrigated Continuous Corn Yields. Agron. J. 2006, 98, 63-71. [CrossRef] 
10. Huang, L.; Riggins, C.; Rodríguez-Zas, S.; Zabaloy, M.; Villamil, M. Long-term N fertilization imbalances potential N acquisition and transformations by soil microbes. Sci. Total Environ. 2019, 691, 562-571. [CrossRef]

11. Benizri, E.; Dedourge-Geffard, O.; Dibattista-Leboeuf, C.; Piutti, S.; Nguyen, C.; Guckert, A. Effect of maize rhizodeposits on soil microbial community structure. Appl. Soil Ecol. 2002, 21, 261-265. [CrossRef]

12. McDaniel, M.; Grandy, A.; Tiemann, L.; Weintraub, M. Crop rotation complexity regulates the decomposition of high and low quality residues. Soil Biol. Biochem. 2014, 78, 243-254. [CrossRef]

13. Navarro-Noya, Y.E.; Gómez-Acata, S.; Montoya-Ciriaco, N.; Rojas-Valdez, A.; Suárez-Arriaga, M.C.; Valenzuela-Encinas, C.; Jiménez-Bueno, N.; Verhulst, N.; Govaerts, B.; Dendooven, L. Relative impacts of tillage, residue management and crop-rotation on soil bacterial communities in a semi-arid agroecosystem. Soil Biol. Biochem. 2013, 65, 86-95. [CrossRef]

14. Ouyang, Y.; Evans, S.E.; Friesen, M.L.; Tiemann, L.K. Effect of nitrogen fertilization on the abundance of nitrogen cycling genes in agricultural soils: A meta-analysis of field studies. Soil Biol. Biochem. 2018, 127, 71-78. [CrossRef]

15. Soman, C.; Li, D.; Wander, M.M.; Kent, A.D. Long-term fertilizer and crop-rotation treatments differentially affect soil bacterial community structure. Plant Soil 2017, 413, 145-159. [CrossRef]

16. Smith, C.R.; Blair, P.L.; Boyd, C.; Cody, B.; Hazel, A.; Hedrick, A.; Kathuria, H.; Khurana, P.; Kramer, B.; Muterspaw, K.; et al. Microbial community responses to soil tillage and crop rotation in a corn/soybean agroecosystem. Ecol. Evol. 2016, 6, 8075-8084. [CrossRef] [PubMed]

17. Beare, M.H.; Hendrix, P.F.; Coleman, D.C. Water-Stable Aggregates and Organic Matter Fractions in Conventional- and No-Tillage Soils. Soil Sci. Soc. Am. J. 1994, 58, 777-786. [CrossRef]

18. Martens, D.A. Management and Crop Residue Influence Soil Aggregate Stability. J. Environ. Qual. 2000, 29, 723-727. [CrossRef]

19. Zuber, S.; Behnke, G.D.; Nafziger, E.D.; Villamil, M.B. Crop Rotation and Tillage Effects on Soil Physical and Chemical Properties in Illinois. Agron. J. 2015, 107, 971-978. [CrossRef]

20. Zuber, S.; Villamil, M.B. Meta-analysis approach to assess effect of tillage on microbial biomass and enzyme activities. Soil Biol. Biochem. 2016, 97, 176-187. [CrossRef]

21. de Graaff, M.-A.; Hornslein, N.; Throop, H.L.; Kardol, P.; van Diepen, L.T.A. Chapter One-Effects of agricultural intensi-fication on soil biodiversity and implications for ecosystem functioning: A meta-analysis. In Advances in Agronomy; Sparks, D.L., Ed.; Academic Press: Cambridge, MA, USA, 2019; Volume 155, pp. 1-44.

22. Sun, R.; Zhang, P.; Riggins, C.; Zabaloy, M.C.; Rodríguez-Zas, S.; Villamil, M.B. Long-Term N Fertilization Decreased Diversity and Altered the Composition of Soil Bacterial and Archaeal Communities. Agronomy 2019, 9, 574. [CrossRef]

23. Kim, N.; Zabaloy, M.C.; Riggins, C.W.; Rodríguez-Zas, S.; Villamil, M.B. Microbial Shifts Following Five Years of Cover Cropping and Tillage Practices in Fertile Agroecosystems. Microorganisms 2020, 8, 1773. [CrossRef]

24. Wolińska, A.; Kuźniar, A.; Zielenkiewicz, U.; Banach, A.; Błaszczyk, M. Indicators of arable soils fatigue-Bacterial families and genera: A metagenomic approach. Ecol. Indic. 2018, 93, 490-500. [CrossRef]

25. Behnke, G.; Zabaloy, M.; Riggins, C.; Rodríguez-Zas, S.; Huang, L.; Villamil, M. Acidification in corn monocultures favor fungi, ammonia oxidizing bacteria, and nirK-denitrifier groups. Sci. Total Environ. 2020, 720, 137514. [CrossRef] [PubMed]

26. Fierer, N.; Jackson, J.A.; Vilgalys, R.; Jackson, R.B. Assessment of Soil Microbial Community Structure by Use of Taxon-Specific Quantitative PCR Assays. Appl. Environ. Microbiol. 2005, 71, 4117-4120. [CrossRef] [PubMed]

27. Neupane, A.; Bulbul, I.; Wang, Z.; Lehman, R.M.; Nafziger, E.; Marzano, S.-Y.L. Long term crop rotation effect on subsequent soybean yield explained by soil and root-associated microbiomes and soil health indicators. Sci. Rep. 2021, 11, 9200. [CrossRef]

28. Web-Soil-Survey. Available online: https:/ / websoilsurvey.sc.egov.usda.gov/App/HomePage.htm (accessed on 11 November 2016).

29. Nafziger, E.D. Illinois Agronomy Handbook; University of Illinois at Urbana-Champaign: Champaign, IL, USA, 2009.

30. Colman, D.R.; Thomas, R.; Maas, K.R.; Takacs-Vesbach, C.D. Detection and analysis of elusive members of a novel and diverse archaeal community within a thermal spring streamer consortium. Extremophiles 2015, 19, 307-313. [CrossRef] [PubMed]

31. Crawford, J.; Deacon, L.; Grinev, D.; Harris, J.A.; Ritz, K.; Singh, B.; Young, I. Microbial diversity affects self-organization of the soil-microbe system with consequences for function. J. R. Soc. Interface 2011, 9, 1302-1310. [CrossRef]

32. Hall, M.; Beiko, R.G. $16 \mathrm{~S}$ rRNA Gene Analysis with QIIME2. In RNA Remodeling Proteins; Springer Science and Business Media LLC: Berlin/Heidelberg, Germany, 2018; pp. 113-129.

33. Bolyen, E.; Rideout, J.R.; Dillon, M.R.; Bokulich, N.A.; Abnet, C.C.; Al-Ghalith, G.A.; Alexander, H.; Alm, E.J.; Arumugam, M.; Asnicar, F.; et al. Reproducible, interactive, scalable and extensible microbiome data science using QIIME 2. Nat. Biotechnol. 2019, 37, 852-857. [CrossRef]

34. Li, X.; Nair, A.; Wang, S.; Wang, L. Quality Control of RNA-Seq Experiments. In Methods in Molecular Biology; Springer Science and Business Media LLC: Berlin/Heidelberg, Germany, 2015; Volume 1269, pp. 137-146.

35. Callahan, B.J.; Mcmurdie, P.J.; Rosen, M.J.; Han, A.W.; Johnson, A.J.A.; Holmes, S.P. DADA2: High-resolution sample inference from Illumina amplicon data. Nat. Methods 2016, 13, 581-583. [CrossRef]

36. Rozewicki, J.; Li, S.; Amada, K.M.; Standley, D.M.; Katoh, K. MAFFT-DASH: Integrated protein sequence and structural alignment. Nucleic Acids Res. 2019, 47, W5-W10. [CrossRef] [PubMed]

37. Nakamura, T.; Yamada, K.D.; Tomii, K.; Katoh, K. Parallelization of MAFFT for large-scale multiple sequence alignments. Bioinformatics 2018, 34, 2490-2492. [CrossRef]

38. Tracy, B.; Coopersmith, C.; Silverman, M.; Fassler, M.; McCarty, E.; Gelbard, R. 1753: Bootstrap forest model predicts neurostimulant therapy after severe traumatic brain injury. Crit. Care Med. 2020, 48. [CrossRef] 
39. Louis, I.V.-S.; Chang, C.C.; Shahid, S.; A French, M.; Bohjanen, P.R. Transcriptomic Predictors of Paradoxical CryptococcosisAssociated Immune Reconstitution Inflammatory Syndrome. Open Forum Infect. Dis. 2018, 5, 5. [CrossRef]

40. Tabachnick, B.G.; Fidell, L.S.; Ullman, J.B. Using Multivariate Statistics; Pearson: Boston, MA, USA, 2007 ; Volume 5.

41. Storey, J.D. The positive false discovery rate: A Bayesian interpretation and the $q$-value. Ann. Stat. 2003, 31, 2013-2035. [CrossRef]

42. Necpalova, M.; Anex, R.P.; Kravchenko, A.N.; Abendroth, L.J.; Del Grosso, S.J.; Dick, W.A.; Helmers, M.J.; Herzmann, D.; Lauer, J.G.; Nafziger, E.D.; et al. What does it take to detect a change in soil carbon stock? A regional comparison of minimum detectable difference and experiment duration in the north central United States. J. Soil Water Conserv. 2014, 69, 517-531. [CrossRef]

43. Ding, J.; Jiang, X.; Ma, M.; Zhou, B.; Guan, D.; Zhao, B.; Zhou, J.; Cao, F.; Li, L.; Li, J. Effect of 35 years inorganic fertilizer and manure amendment on structure of bacterial and archaeal communities in black soil of northeast China. Appl. Soil Ecol. 2016, 105, 187-195. [CrossRef]

44. Zhang, Y.; Shen, H.; He, X.; Thomas, B.; Lupwayi, N.Z.; Hao, X.; Thomas, M.C.; Shi, X. Fertilization Shapes Bacterial Community Structure by Alteration of Soil pH. Front. Microbiol. 2017, 8, 1325. [CrossRef] [PubMed]

45. Buyanovsky, G.A.; Wagner, G.H. Post-harvest residue input to cropland. Plant Soil 1986, 93, 57-65. [CrossRef]

46. Kaboneka, S.; Sabbe, W.E.; Mauromoustakos, A. Carbon decomposition kinetics and nitrogen mineralization from corn, soybean, and wheat residues. Commun. Soil Sci. Plant Anal. 1997, 28, 1359-1373. [CrossRef]

47. Coyotzi, S.; Doxey, A.C.; Clark, I.D.; Lapen, D.R.; van Cappellen, P.; Neufeld, J.D. Agricultural soil denitrifiers possess extensive nitrite reductase gene diversity. Environ. Microbiol. 2017, 19, 1189-1208. [CrossRef]

48. Green, S.J.; Prakash, O.; Gihring, T.M.; Akob, D.; Jasrotia, P.; Jardine, P.M.; Watson, D.; Brown, S.D.; Palumbo, A.V.; Kostka, J.E. Denitrifying Bacteria Isolated from Terrestrial Subsurface Sediments Exposed to Mixed-Waste Contamination. Appl. Environ. Microbiol. 2010, 76, 3244-3254. [CrossRef]

49. Staley, C.; Breuillin-Sessoms, F.; Wang, P.; Kaiser, T.; Venterea, R.T.; Sadowsky, M.J. Urea Amendment Decreases Microbial Diversity and Selects for Specific Nitrifying Strains in Eight Contrasting Agricultural Soils. Front. Microbiol. 2018, 9, 634. [CrossRef]

50. Bailey, V.L.; Fansler, S.J.; Stegen, J.; McCue, L.A. Linking microbial community structure to $\beta$-glucosidic function in soil aggregates. ISME J. 2013, 7, 2044-2053. [CrossRef] [PubMed]

51. Jones, R.T.; Robeson, M.; Lauber, C.L.; Hamady, M.; Knight, R.; Fierer, N. A comprehensive survey of soil acidobacterial diversity using pyrosequencing and clone library analyses. ISME J. 2009, 3, 442-453. [CrossRef]

52. Sait, M.; Davis, K.E.R.; Janssen, P.H. Effect of $\mathrm{pH}$ on Isolation and Distribution of Members of Subdivision 1 of the Phylum Acidobacteria Occurring in Soil. Appl. Environ. Microbiol. 2006, 72, 1852-1857. [CrossRef]

53. Wang, X.; He, T.; Gen, S.; Zhang, X.-Q.; Wang, X.; Jiang, D.; Li, C.; Li, C.; Wang, J.; Zhang, W.; et al. Soil properties and agricultural practices shape microbial communities in flooded and rainfed croplands. Appl. Soil Ecol. 2020, 147, 103449. [CrossRef]

54. Wang, H.; Zeng, Y.; Guo, C.; Bao, Y.; Lu, G.; Reinfelder, J.R.; Dang, Z. Bacterial, archaeal, and fungal community responses to acid mine drainage-laden pollution in a rice paddy soil ecosystem. Sci. Total Environ. 2018, 616-617, 107-116. [CrossRef] [PubMed]

55. Ward, N.L.; Challacombe, J.F.; Janssen, P.H.; Henrissat, B.; Coutinho, P.M.; Wu, M.; Xie, G.; Haft, D.H.; Sait, M.; Badger, J.; et al. Three Genomes from the Phylum Acidobacteria Provide Insight into the Lifestyles of These Microorganisms in Soils. Appl. Environ. Microbiol. 2009, 75, 2046-2056. [CrossRef]

56. Yu, W.; Lawrence, N.C.; Sooksa-Nguan, T.; Smith, S.D.; Tenesaca, C.; Howe, A.C.; Hall, S.J. Microbial linkages to soil biogeochemical processes in a poorly drained agricultural ecosystem. Soil Biol. Biochem. 2021, 156, 108228. [CrossRef]

57. Chen, W.-C.; Ko, C.-H.; Su, Y.-S.; Lai, W.-A.; Shen, F.-T. Metabolic potential and community structure of bacteria in an organic tea plantation. Appl. Soil Ecol. 2021, 157, 103762. [CrossRef]

58. Bräuer, S.; Harbison, A.; Ueki, A. Micropepsales. In Bergey's Manual of Systematics of Archaea and Bacteria; Wiley: Hoboken, NJ, USA, 2015; p. 1.

59. Gomes, S.I.F.; van Bodegom, P.M.; van Agtmaal, M.; Soudzilovskaia, N.A.; Bestman, M.; Duijm, E.; Speksnijder, A.; van Eekeren, N Microbiota in Dung and Milk Differ Between Organic and Conventional Dairy Farms. Front. Microbiol. 2020, 11, 1746. [CrossRef]

60. Dedysh, S.N.; Beletsky, A.V.; Ivanova, A.A.; Kulichevskaya, I.S.; Suzina, N.E.; Philippov, D.A.; Rakitin, A.L.; Mardanov, A.V.; Ravin, N.V. Wide distribution of Phycisphaera-like planctomycetes from WD2101 soil group in peatlands and genome analysis of the first cultivated representative. Environ. Microbiol. 2021, 23, 1510-1526. [CrossRef]

61. Yabe, S.; Sakai, Y.; Abe, K.; Yokota, A. Diversity of Ktedonobacteria with Actinomycetes-Like Morphology in Terrestrial Environments. Microbes Environ. 2017, 32, 61-70. [CrossRef]

62. Eo, J.; Park, K.-C.; Kim, M.-H. Plant-specific effects of sunn hemp (Crotalaria juncea) and sudex (Sorghum bicolor $\times$ Sorghum bicolor var. sudanense) on the abundance and composition of soil microbial community. Agric. Ecosyst. Environ. 2015, 213, 86-93. [CrossRef]

63. Lupwayi, N.Z.; May, W.E.; Kanashiro, D.A.; Petri, R. Soil bacterial community responses to black medic cover crop and fertilizer N under no-till. Appl. Soil Ecol. 2018, 124, 95-103. [CrossRef]

64. Cai, Y.; Shen, J.-P.; Di, H.J.; Zhang, L.-M.; Zhang, C.; He, J.-Z. Variation of soil nitrate and bacterial diversity along soil profiles in manure disposal maize field and adjacent woodland. J. Soils Sediments 2020, 20, 3557-3568. [CrossRef]

65. Li, Y.; Chen, L.; Wen, H.; Zhou, T.; Zhang, T.; Gao, X. 454 Pyrosequencing Analysis of Bacterial Diversity Revealed by a Comparative Study of Soils from Mining Subsidence and Reclamation Areas. J. Microbiol. Biotechnol. 2014, 24, 313-323. [CrossRef] [PubMed] 
66. Chen, Y.; Xin, L.; Liu, J.; Yuan, M.; Liu, S.; Jiang, W.; Chen, J. Changes in bacterial community of soil induced by long-term straw returning. Sci. Agric. 2017, 74, 349-356. [CrossRef]

67. Eisenlord, S.; Zak, D. Simulated Atmospheric Nitrogen Deposition Alters Actinobacterial Community Composition in Forest Soils. Soil Biol. Biochem. 2009, 74, 1157-1166. [CrossRef]

68. Shange, R.S.; Ankumah, R.O.; Ibekwe, A.M.; Zabawa, R.; Dowd, S. Distinct Soil Bacterial Communities Revealed under a Diversely Managed Agroecosystem. PLoS ONE 2012, 7, e40338. [CrossRef] [PubMed]

69. Zhang, B.; Wu, X.; Tai, X.; Sun, L.; Wu, M.; Zhang, W.; Chen, X.; Zhang, G.; Chen, T.; Liu, G.; et al. Variation in Actinobacterial Community Composition and Potential Function in Different Soil Ecosystems Belonging to the Arid Heihe River Basin of Northwest China. Front. Microbiol. 2019, 10, 2209. [CrossRef] [PubMed]

70. Wang, X.; Yang, H.-X.; Zhang, Y.-K.; Zhu, S.-J.; Liu, X.-W.; Zhang, H.; Zhang, C.-F.; Zhao, C.-R.; Hu, G.; Hong, Q. Luteimonas soli sp. nov., isolated from farmland soil. Int. J. Syst. Evol. Microbiol. 2015, 65, 4809-4815. [CrossRef] [PubMed]

71. Simmons, C.W.; Claypool, J.; Marshall, M.N.; Jabusch, L.K.; Reddy, A.P.; Simmons, B.A.; Singer, S.W.; Stapleton, J.; VanderGheynst, J.S. Characterization of bacterial communities in solarized soil amended with lignocellulosic organic matter. Appl. Soil Ecol. 2014, 73, 97-104. [CrossRef]

72. Xiao, X.; Fan, M.; Wang, E.; Chen, W.; Weimin, C. Interactions of plant growth-promoting rhizobacteria and soil factors in two leguminous plants. Appl. Microbiol. Biotechnol. 2017, 101, 8485-8497. [CrossRef] [PubMed]

73. Zhou, Y.; Qin, Y.; Liu, X.; Feng, Z.; Zhu, H.; Yao, Q. Soil Bacterial Function Associated With Stylo (Legume) and Bahiagrass (Grass) is Affected More Strongly by Soil Chemical Property Than by Bacterial Community Composition. Front. Microbiol. 2019, 10, 798. [CrossRef] [PubMed]

74. Ivanova, A.A.; Zhelezova, A.D.; Chernov, T.I.; Dedysh, S.N. Linking ecology and systematics of acidobacteria: Distinct habitat preferences of the Acidobacteriia and Blastocatellia in tundra soils. PLoS ONE 2020, 15, e0230157. [CrossRef]

75. Song, A.; Li, Z.; Liao, Y.; Liang, Y.; Wang, E.; Wang, S.; Li, X.; Bi, J.; Si, Z.; Lu, Y.; et al. Soil bacterial communities interact with silicon fraction transformation and promote rice yield after long-term straw return. Soil Ecol. Lett. 2021, 1-14. [CrossRef]

76. De Chaves, M.G.; Silva, G.G.Z.; Rossetto, R.; Edwards, R.A.; Tsai, S.M.; Navarrete, A.A. Acidobacteria Subgroups and Their Metabolic Potential for Carbon Degradation in Sugarcane Soil Amended with Vinasse and Nitrogen Fertilizers. Front. Microbiol. 2019, 10, 1680. [CrossRef]

77. Navarrete, A.A.; Kuramae, E.E.; de Hollander, M.; Pijl, A.S.; van Veen, J.A.; Tsai, S.M. Acidobacterial community responses to agricultural management of soybean in Amazon forest soils. FEMS Microbiol. Ecol. 2013, 83, 607-621. [CrossRef]

78. Kielak, A.M.; Barreto, C.; Kowalchuk, G.A.; van Veen, J.A.; Kuramae, E.E. The Ecology of Acidobacteria: Moving beyond Genes and Genomes. Front. Microbiol. 2016, 7, 744. [CrossRef]

79. Dedysh, S.N.; Damsté, J.S.S. Acidobacteria. In eLS; Wiley: Hoboken, NJ, USA, 2018; pp. 1-10.

80. Kulichevskaya, I.S.; Suzina, N.E.; Rijpstra, W.I.C.; Damsté, J.S.S.; Dedysh, S.N. Paludibaculum fermentans gen. nov., sp. nov., a facultative anaerobe capable of dissimilatory iron reduction from subdivision 3 of the Acidobacteria. Int. J. Syst. Evol. Microbiol. 2014, 64, 2857-2864. [CrossRef]

81. Amend, A.S.; Martiny, A.C.; Allison, S.D.; Berlemont, R.; Goulden, M.L.; Lu, Y.; Treseder, K.K.; Weihe, C.; Martiny, J. Microbial response to simulated global change is phylogenetically conserved and linked with functional potential. ISME J. 2015, 10, 109-118. [CrossRef]

82. Ling, N.; Chen, D.; Guo, H.; Wei, J.; Bai, Y.; Shen, Q.; Hu, S. Differential responses of soil bacterial communities to long-term N and $\mathrm{P}$ inputs in a semi-arid steppe. Geoderma 2017, 292, 25-33. [CrossRef]

83. Isobe, K.; Allison, S.D.; Khalili, B.; Martiny, A.C.; Martiny, J.B. Phylogenetic conservation of bacterial responses to soil ni-trogen addition across continents. Nat. Commun. 2019, 10, 2499. [CrossRef] [PubMed]

84. Dawid, W. Biology and global distribution of myxobacteria in soils. FEMS Microbiol. Rev. 2000, 24, 403-427. [CrossRef]

85. Wang, W.; Luo, X.; Ye, X.; Chen, Y.; Wang, H.; Wang, L.; Wang, Y.; Yang, Y.; Li, Z.; Cao, H.; et al. Predatory Myxococcales are widely distributed in and closely correlated with the bacterial community structure of agricultural land. Appl. Soil Ecol. 2020, 146, 103365. [CrossRef]

86. Zhou, Y.; Zhang, X.; Yao, Q.; Zhu, H. Both Soil Bacteria and Soil Chemical Property Affected the Micropredator Myxobacterial Community: Evidence from Natural Forest Soil and Greenhouse Rhizosphere Soil. Microorganisms 2020, 8, 1387. [CrossRef] [PubMed]

87. Tripathi, B.M.; Kim, M.; Singh, D.; Lee-Cruz, L.; Lai-Hoe, A.; Ainuddin, A.N.; Go, R.; Rahim, R.A.; Husni, M.H.A.; Chun, J.; et al. Tropical Soil Bacterial Communities in Malaysia: pH Dominates in the Equatorial Tropics Too. Microb. Ecol. 2012, 64, 474-484. [CrossRef]

88. Kandasamy, S.; Weerasuriya, N.; White, J.F.; Patterson, G.; Lazarovits, G. Chapter 23-Soil's physical and nutritional balance is essential for establishing a healthy microbiome. In Microbiome Stimulants for Crops; White, J., Kumar, A., Droby, S., Eds.; Woodhead Publishing: Amsterdam, The Netherlands, 2021; pp. 381-404.

89. Löffler, F.E.; Yan, J.; Ritalahti, K.M.; Adrian, L.; Edwards, E.; Konstantinidis, K.T.; Müller, J.A.; Fullerton, H.; Zinder, S.H.; Spormann, A.M. Dehalococcoides mccartyi gen. nov., sp. nov., obligately organohalide-respiring anaerobic bacteria relevant to halogen cycling and bioremediation, belong to a novel bacterial class, Dehalococcoidia classis nov., order Dehalococcoidales ord. nov. and family Dehalococcoidaceae fam. nov., within the phylum Chloroflexi. Int. J. Syst. Evol. Microbiol. 2013, 63, 625-635. [CrossRef] 
90. Yang, Y.; Sanford, R.; Yan, J.; Chen, G.; Cápiro, N.L.; Li, X.; Löffler, F.E. Roles of Organohalide-Respiring Dehalococcoidia in Carbon Cycling. mSystems 2020, 5. [CrossRef]

91. Sheng, R.; Meng, D.; Wu, M.; Di, H.; Qin, H.; Wei, W. Effect of agricultural land use change on community composition of bacteria and ammonia oxidizers. J. Soils Sediments 2013, 13, 1246-1256. [CrossRef]

92. Yao, R.; Yang, J.; Wang, X.; Zheng, F.; Xie, W.; Li, H.; Tang, C.; Zhu, H. Response of soil characteristics and bacterial communities to a gradient of $\mathrm{N}$ fertilization rates for coastal salt-affected Fluvo-aquic soil under paddy rice-winter wheat rotation. Authorea 2020. [CrossRef]

93. Yamada, T.; Sekiguchi, Y.; Hanada, S.; Imachi, H.; Ohashi, A.; Harada, H.; Kamagata, Y. Anaerolinea thermolimosa sp. nov., Levilinea saccharolytica gen. nov., sp. nov. and Leptolinea tardivitalis gen. nov., sp. nov., novel filamentous anaerobes, and description of the new classes Anaerolineae classis nov. and Caldilineae classis nov. in the bacterial phylum Chloroflexi. Int. J. Syst. Evol. Microbiol. 2006, 56, 1331-1340. [CrossRef]

94. Cai, X.; Wen, P.; Yuan, Y.; Tang, J.; Yu, Z.; Zhou, S. Identification of nitrogen-incorporating bacteria in a sequencing batch reactor: A combining cultivation-dependent and cultivation-independent method. Bioresour. Technol. 2020, $316,123964$. [CrossRef] [PubMed]

95. Bziuk, N.; Maccario, L.; Douchkov, D.; Lueck, S.; Babin, D.; Sørensen, S.J.; Schikora, A.; Smalla, K. Tillage shapes the soil and rhizosphere microbiome of barley-But not its susceptibility towards Blumeria graminis f. sp. hordei. FEMS Microbiol. Ecol. 2021, 97, 018. [CrossRef]

96. Ghai, R.; Mizuno, C.M.; Picazo, A.; Camacho, A.; Rodriguez-Valera, F. Metagenomics uncovers a new group of low GC and ultra-small marine Actinobacteria. Sci. Rep. 2013, 3, srep02471. [CrossRef] [PubMed]

97. Du, X.; Liu, J.; Xue, Y.; Kong, X.; Lv, C.; Li, Z.; Huang, Y.; Wang, B. Alteration of gut microbial profile in patients with diabetic nephropathy. Endocrine 2021, 1-14. [CrossRef]

98. Leslie, J.F.; Summerell, B.A. The Fusarium Laboratory Manual; John Wiley \& Sons: Hoboken, NJ, USA, 2008.

99. Moya-Elizondo, E.A.; Arismendi, N.; Montalva, C.; Doussoulin, H. First Report of Fusarium sporotrichioides Causing Foliar Spots on Forage Corn in Chile. Plant. Dis. 2013, 97, 1113. [CrossRef]

100. Zitnick-Anderson, K.; Mendoza, L.E.D.R.; Forster, S.; Pasche, J.S. Associations among the communities of soil-borne pathogens, soil edaphic properties and disease incidence in the field pea root rot complex. Plant Soil 2020, 457, 339-354. [CrossRef]

101. Sharma-Poudyal, D.; Schlatter, D.; Yin, C.; Hulbert, S.; Paulitz, T. Long-term no-till: A major driver of fungal communities in dryland wheat cropping systems. PLoS ONE 2017, 12, e0184611. [CrossRef]

102. Gałązka, A.; Grządziel, J. Fungal Genetics and Functional Diversity of Microbial Communities in the Soil under Long-Term Monoculture of Maize Using Different Cultivation Techniques. Front. Microbiol. 2018, 9, 76. [CrossRef] [PubMed]

103. Schmidt, R.; Mitchell, J.; Scow, K. Cover cropping and no-till increase diversity and symbiotroph:saprotroph ratios of soil fungal communities. Soil Biol. Biochem. 2019, 129, 99-109. [CrossRef]

104. Degrune, F.; Theodorakopoulos, N.; Colinet, G.; Hiel, M.-P.; Bodson, B.; Taminiau, B.; Daube, G.; Vandenbol, M.; Hartmann, M. Temporal Dynamics of Soil Microbial Communities below the Seedbed under Two Contrasting Tillage Regimes. Front. Microbiol. 2017, 8, 1127. [CrossRef] [PubMed]

105. Wang, H.; Guo, Q.; Li, X.; Li, X.; Yu, Z.; Li, X.; Yang, T.; Su, Z.; Zhang, H.; Zhang, C. Effects of long-term no-tillage with different straw mulching frequencies on soil microbial community and the abundances of two soil-borne pathogens. Appl. Soil Ecol. 2020, 148, 103488. [CrossRef]

106. Sun, R.; Li, W.; Dong, W.; Tian, Y.; Hu, C.; Liu, B. Tillage Changes Vertical Distribution of Soil Bacterial and Fungal Communities. Front. Microbiol. 2018, 9, 699. [CrossRef]

107. Lehtovirta-Morley, L.; Stoecker, K.; Vilcinskas, A.; Prosser, J.I.; Nicol, G. Cultivation of an obligate acidophilic ammonia oxidizer from a nitrifying acid soil. Proc. Natl. Acad. Sci. USA 2011, 108, 15892-15897. [CrossRef]

108. Baolan, H.; Shuai, L.; Wei, W.; Lidong, S.; Liping, L.; Weiping, L.; Guangming, T.; Xiangyang, X.; Ping, Z. pH-dominated niche segregation of ammonia-oxidising microorganisms in Chinese agricultural soils. FEMS Microbiol. Ecol. 2014, 90, 290-299. [CrossRef]

109. Herbold, C.W.; Lehtovirta-Morley, L.E.; Jung, M.-Y.; Jehmlich, N.; Hausmann, B.; Han, P.; Loy, A.; Pester, M.; Sayavedra-Soto, L.A.; Rhee, S.-K.; et al. Ammonia-oxidising archaea living at low pH: Insights from comparative genomics. Environ. Microbiol. 2017, 19, 4939-4952. [CrossRef]

110. Papadopoulou, E.S.; Bachtsevani, E.; Lampronikou, E.; Adamou, E.; Katsaouni, A.; Vasileiadis, S.; Thion, C.; MenkissogluSpiroudi, U.; Nicol, G.W.; Karpouzas, D.G. Comparison of Novel and Established Nitrification Inhibitors Relevant to Agriculture on Soil Ammonia- and Nitrite-Oxidizing Isolates. Front. Microbiol. 2020, 11, 581283. [CrossRef]

111. Lehtovirta-Morley, L.; Verhamme, D.T.; Nicol, G.W.; Prosser, J.I. Effect of nitrification inhibitors on the growth and activity of Nitrosotalea devanaterra in culture and soil. Soil Biol. Biochem. 2013, 62, 129-133. [CrossRef]

112. Turon, M.; Uriz, M.J. New Insights into the Archaeal Consortium of Tropical Sponges. Front. Mar. Sci. 2020, 6. [CrossRef]

113. Juottonen, H.; Fontaine, L.; Wurzbacher, C.; Drakare, S.; Peura, S.; Eiler, A. Archaea in boreal Swedish lakes are diverse, dominated by Woesearchaeota and follow deterministic community assembly. Environ. Microbiol. 2020, 22, 3158-3171. [CrossRef] [PubMed]

114. Wang, H.; Bier, R.; Zgleszewski, L.; Peipoch, M.; Omondi, E.; Mukherjee, A.; Chen, F.; Zhang, C.; Kan, J. Distinct Distribution of Archaea From Soil to Freshwater to Estuary: Implications of Archaeal Composition and Function in Different Environments. Front. Microbiol. 2020, 11, 576661. [CrossRef] [PubMed] 
115. Wang, B.; Zheng, X.; Zhang, H.; Xiao, F.; He, Z.; Yan, Q. Keystone taxa of water microbiome respond to environmental quality and predict water contamination. Environ. Res. 2020, 187, 109666. [CrossRef]

116. Wang, S.; Zheng, X.; Xia, H.; Shi, D.; Fan, J.; Wang, P.; Yan, Z. Archaeal community variation in the Qinhuangdao coastal aquaculture zone revealed by high-throughput sequencing. PLoS ONE 2019, 14, e0218611. [CrossRef] [PubMed]

117. Villamil, M.B. Microbial indicators in agriculture. Mendeley Data 2021, 2. [CrossRef] 